\title{
Focus on cutaneous and uveal melanoma specificities
}

\author{
Charlotte Pandiani, Guillaume E. Béranger, Justine Leclerc, Robert Ballotti, and Corine Bertolotto \\ U1065, Institut National de la Santé et de la Recherche Médicale Centre Méditerranéen de Médecine Moléculaire, Université Côte \\ d'Azur, 06200 Nice, France
}

Cutaneous melanoma (CM) and uveal melanoma (UM) derive from cutaneous and uveal melanocytes that share the same embryonic origin and display the same cellular function. However, the etiopathogenesis and biological behaviors of these melanomas are very different. $\mathrm{CM}$ and $U M$ display distinct landscapes of genetic alterations and show different metastatic routes and tropisms. Hence, therapeutic improvements achieved in the last few years for the treatment of CM have failed to ameliorate the clinical outcomes of patients with UM. The scope of this review is to discuss the differences in tumorigenic processes (etiologic factors and genetic alterations) and tumor biology (gene expression and signaling pathways) between CM and UM. We develop hypotheses to explain these differences, which might provide important clues for research avenues and the identification of actionable vulnerabilities suitable for the development of new therapeutic strategies for metastatic UM.

\section{Physiological function of melanocytes}

Melanocytes are cells responsible for the synthesis of melanin pigments within organelles called melanosomes through an enzymatic cascade involving tyrosinase, tyrosinase-related protein-1 (TYRP1), and TYRP2/DCT (dopachrome tautomerase). Two types of pigment are produced: the brown/black pigment eumelanin and the orange/yellow pigment pheomelanin; the latter is formed in the presence of cysteine or glutathione. The proportion of these two types of melanin defines the variation in skin and iris color. The ratio of eumelanin/pheomelanin is significantly greater in both dark brown skin and eyes than in pale skin and eyes with light-colored irises (hazel, green, yellow-brown, and blue in color) (Rees 2004; Wakamatsu et al. 2008).

Melanocytes derive from neural crest cells. These undifferentiated cells, called melanoblasts, migrate to their

[Keywords: cancer; melanoma; skin]

Corresponding author: bertolot@unice.fr

Article is online at http://www.genesdev.org/cgi/doi/10.1101/gad.296962. 117. final location, where they synthesize melanin. They are found in various parts of the human body, such as the skin, eyes, meninges, heart, and cochlea. The role and function of melanocytes are well established in skin but not in other anatomical locations.

In the epidermis, melanocytes transfer melanin-containing melanosomes to neighboring keratinocytes to ensure homogeneous pigmentation and provide efficient skin protection against the harmful effects of ultraviolet radiation (UVR) from solar light (Brenner and Hearing 2008).

In the eyes, melanocytes can be found in (1) the conjunctiva, a nonkeratinized epithelium that covers the anterior part of the sclera and the internal surface of the eyelids, and (2) all areas of the uvea: the iris, ciliary body, and choroid. The role of melanocytes in the conjunctiva remains unknown. The quantity and quality of melanin pigment in the iris determine eye color. However, in contrast to the skin, the iris color remains stable after exposure to sunlight. Furthermore, the presence of melanin in uveal melanocytes is thought to contribute to eye protection against ocular diseases that can cause blindness, including age-related macular degeneration and uveal melanoma (UM) (Sarna 1992). However, how melanin mediates this protection remains mostly unknown.

The presence of melanocytes in organs that are not exposed to UVR indicates that these cells might have functions other than those solely related to photoprotection. Melanocytes in the stria vascularis of the cochlea are involved in the generation of endolymph-mediated action potentials necessary for normal hearing (Barrenas and Lindgren 1990; Tachibana 1999) and in equilibrium function (Takeda et al. 2007). Brain melanocytes are associated with neuroendocrine functions and may also protect against oxidative damage (Zecca et al. 2008). Heart melanocytes play a role in the mechanical properties of the valves (Carneiro et al. 2015) and have been shown to be involved in atrial arrhythmia (Levin et al. 2009).

(C) 2017 Pandiani et al. This article is distributed exclusively by Cold Spring Harbor Laboratory Press for the first six months after the full-issue publication date (see http://genesdev.cshlp.org/site/misc/terms.xhtml). After six months, it is available under a Creative Commons License (Attribution-NonCommercial 4.0 International), as described at http:// creativecommons.org/licenses/by-nc/4.0/. 
In this review, we provide several hypotheses to explain why cells sharing the same embryonic origin and cellular functions (i.e., melanin synthesis) are subjected to different tumor transformation processes. We discuss the biological and genetic differences between skin and eye melanomas and, based on these differences, how treatment and clinical outcomes are affected (Table 1).

\section{Classification and prognosis of cutaneous melanoma $(\mathrm{CM})$ and ocular melanoma (OM)}

Both CM and OM arise from melanocyte transformation and represent deadly forms of cancer. Their rate is higher among Caucasians compared with African Americans (McLaughlin et al. 2005; Jovanovic et al. 2013). In most cases, they both occur de novo but can also develop from pre-existing melanocytic lesions such as nevi or primary acquired melanocytosis (Tsao et al. 2003; Jovanovic et al. 2013).

The incidence of CM, which develops from cutaneous melanocytes, has increased dramatically in white popula- tions over the past several decades to reach 230,000 new cases worldwide each year (World Health Organization) and accounts for $1.6 \%$ of all diagnosed cancers.

A clinico-anatomical classification (Clark's classification) based on the site of cancer occurrence and histological morphology distinguished the following five types of CM: superficial spreading melanoma, nodular melanoma, lentigo maligna melanoma, mucosal melanoma, and acral melanoma (Clark et al. 1986). Superficial spreading melanoma presents as an enlarging patch during the radial growth phase, which subsequently extends downward through the skin in the vertical growth phase. Nodular melanoma, which presents as a nodule, has a propensity to grow vertically and display aggressive behaviors. Lentigo maligna melanoma grows in diameter slowly over many years. It is associated with cumulative sun exposure and thus is found most often in the elderly. Acral melanoma involves the nonpigmented palmoplantar and subungual areas, and mucosal melanoma can occur in all mucosal surfaces. These lesions have been termed acral lentiginous melanoma because they share several features and often present a lentiginous component (Arrington et al. 1977).

Table 1. Comparison of cutaneous melanoma (CM) and UM features

\begin{tabular}{|c|c|c|c|}
\hline & \multicolumn{2}{|l|}{$\mathrm{OM}$} & \multirow{2}{*}{$\frac{\mathrm{CM}}{\mathrm{SSM}, \mathrm{NM}, \mathrm{AM}, \mathrm{MM}, \mathrm{LM}}$} \\
\hline & UM & Conjunctival melanoma & \\
\hline Incidence worldwide & 8000 & 800 & 230,000 \\
\hline Median survival rate & $2-8 \mathrm{mo}$ & $8 \mathrm{mo}$ & $6-10 \mathrm{mo}$ \\
\hline Hereditary cases & $1 \%-2 \%$ & & $10 \%$ \\
\hline Main susceptibility alleles & OCA2-HERC2, BAP1 & & $\begin{array}{l}\text { Cell cycle (CDKN2A, CDK4, RB1), } \\
\text { DNA damage (BRCA1), telomere } \\
\text { maintenance (TERT, POT1, ACD, } \\
\text { TERF2IP), pigmentation (MC1R, } \\
\text { MITF, TYR, TYRP1, OCA2) }\end{array}$ \\
\hline UV radiation involvement & No & Possible & Yes \\
\hline $\begin{array}{l}\text { Mutation burden } \\
\text { Somatic genetic alterations }\end{array}$ & Low & & High \\
\hline Gain of function & $\begin{array}{l}\text { GNAQ/GNA11, SF3B1, EIF1AX, } \\
\text { CYSTLR2, PLC } \beta 4\end{array}$ & BRAF, NRAS, TERT & $\begin{array}{l}\text { BRAF, NRAS, MEK1/2, PIK3CA, } \\
\text { PIK3CG, AKT1/AKT3, RAC1, } \\
\text { KIT }\end{array}$ \\
\hline Loss of function & BAP1 & & CDKN2A, PTEN, NF1, RASA2 \\
\hline Signaling pathways activation & $\begin{array}{l}\text { ARF6-TRIO-RHO-RAC-YAP } \\
\text { PLC } \beta / \text { PKC }\end{array}$ & & $\begin{array}{l}\text { ERK } \\
\text { PI3K/AKT }\end{array}$ \\
\hline Chromosome anomalies & $\begin{array}{l}\text { "Simple," loss of } 3,1 \mathrm{p} \text {, and } 6 \mathrm{q} \\
\text { and gain of } 6 \mathrm{p} \text { and } 8 \mathrm{q}\end{array}$ & & "Complex" \\
\hline Dissemination & Hematogenous & $\begin{array}{l}\text { Lymphogenous and } \\
\text { hematogenous }\end{array}$ & Lymphogenous and hematogenous \\
\hline Common first metastatic sites & Liver & Regional lymph nodes & Regional lymph nodes \\
\hline Targeted therapies & No & $\begin{array}{l}\text { Anti-BRAF, anti-MEK to } \\
\text { be tested }\end{array}$ & Anti-BRAF, anti-MEK \\
\hline Immunotherapies & Inefficient & No & Anti-CTLA4, anti-PD1, anti-PDL1 \\
\hline
\end{tabular}

(OM) Ocular melanoma; (SSM) superficial spreading melanoma; (NM) nodular melanoma; (AM) acral melanoma; (MM) mucosal melanoma; (LM) lentigo maligna melanoma; (BAP1) BRCA1-associated protein; (CDKN2A) cyclin-dependent kinase (CDK) inhibitor 2A; (BRAF) brain rapidly accelerated fibrosarcoma; (TERT) telomerase reverse transcriptase; (MC1R) melanocortin-1 receptor; (MITF) microphthalmia-associated transcription factor; (GNAQ) guanine nucleotide-binding protein G(q) subunit $\alpha$; (GNA11) guanine nucleotide-binding protein subunit $\alpha-11$; (SF3B1) splicing factor 3B, subunit 1; (EIF1AX) eukaryotic translation initiation factor 1A, X-linked; (PLC $\beta$ ) phospholipase $\mathrm{C} \beta$; (PI3K) phosphatidylinositol-3-kinase; (PKC) protein kinase $\mathrm{C}_{\text {; }}(\mathrm{AKT})$ protein kinase $\mathrm{B}$; (RAC1) Ras-related C3 botulinum toxin substrate 1; (PTEN) phosphatase and tensin homolog; (NF1) neurofibromin 1; (RASA2) RAS (Rous sarcoma) p21 protein activator 2; (ARF6) ADP-ribosylation factor 6; (YAP) yes-associated protein; (ERK) extracellular regulated kinase; (CTLA4) cytotoxic T-lymphocyte-associated protein 4; (PD1) programmed cell death 1; (PDL1) PD ligand 1. 
Very early stage skin-localized melanoma (Breslow $<1$ $\mathrm{mm}$ ) can be cured by wide surgical excision and has a 5yr survival rate of $>98 \%$. In contrast, when diagnosis is delayed, CM becomes increasingly more devastating, and individuals display an increased risk of developing lymph node and visceral metastases. CM is believed to spread mainly via the lymphatic route, although hematogenous diffusion has also been reported (Zbytek et al. 2008). Almost all organs can be involved, but the most common sites for distant CM metastases are the lungs, liver, bones, and brain. Until 2012, studies have shown that patients with distant metastatic CM had a median survival rate typically ranging from 6 to $10 \mathrm{mo}$ and a 5 -yr survival rate of $\sim 15 \%-20 \%$ (Tas 2012).

OM, which originates from eye melanocytes, is the most common primary malignancy in the adult population. OM is classified based on the anatomic site of origin as conjunctival melanoma or UM. The large majority of OM originates from the uvea $(95 \%)$, comprising the posterior uvea (choroid $90 \%$ and ciliary body $5 \%$ ) and the anterior uvea (iris $5 \%$ ). The UM staging system is based on the largest basal tumor diameter, ciliary body involvement, and extraocular involvement (Kujala and Kivela 2005). Approximately 8000 new cases of UM and 800 new cases of conjunctival melanoma are diagnosed worldwide each year. CM is 20-30 times more common than UM and 360-900 times more common than conjunctival melanoma (Singh and Topham 2003; Wong et al. 2014). In contrast to the incidence of UM, which has remained stable over the last three decades, the incidence of conjunctival melanoma is increasing (Triay et al. 2009). In the early stages, UM usually presents as a pigmented choroidal nodular mass in the eye fundus, growing toward the vitreous space with a typical mushroom shape. It can extend through sclera or the optic nerve in advanced stages. Symptoms of UM include blurred vision and seeing flashing lights and shadows, but most UM tumors are initially completely asymptomatic and are diagnosed by an ophthalmologist during a routine sight test, accounting for their frequent late stage diagnosis. Despite successful treatment of the primary tumor, only $1 \%-3 \%$ of patients have detectable extraocular lesions at diagnosis; up to $50 \%$ of patients develop metastases. Consequently, micrometastases appear to be established several years before the diagnosis of UM. UM spreads mainly via the bloodstream (i.e., hematogenously) (Dithmar et al. 2000). In $80 \%-90 \%$ of UM cases, the liver is the most common metastatic site, with the second most common site being the lung (Rietschel et al. 2005; Singh et al. 2005). Importantly, a nonliver first metastasis has been correlated with improved survival. At the metastatic stage, longterm survival is rare. Patients with liver metastases have a median survival time of $2-8 \mathrm{mo}$, and $80 \%$ of patients die within 1 yr (Diener-West et al. 2005). Conjunctival melanoma is a completely different entity and generally presents as a pigmented nodular lesion that is usually on the bulbar conjunctiva and often involves the limbus (Shields et al. 2011b). Most conjunctival tumors do not cause symptoms and are diagnosed during a routine eye examination by an ophthalmologist. Approximately
$20 \%-30 \%$ of people will develop metastatic disease. Conjunctival melanoma disseminates via the lymphatics and the bloodstream to invade the lungs, brain, liver, skin, bones, and gastrointestinal tract but can undergo direct extension to the eyeball and orbit (Kenawy et al. 2013). The melanoma-specific survival rate is $86 \%$ at $5 \mathrm{yr}$ and $71 \%$ at $10 \mathrm{yr}$ (Missotten et al. 2005).

\section{Risk factors and genetic predisposition}

The etiology of melanoma is complex and heterogeneous because it involves environmental, phenotypic, and genetic risk factors.

The major risk factors for CM include a personal and familial history of CM, a large number of nevi/dysplasic nevi, sun exposure, and skin reactions to sun exposure according to the phototype. Approximately $10 \%$ of CM is estimated to exhibit familial inheritance. Mutations in cyclin-dependent kinase (CDK) inhibitor $2 A$ (CDKN2A) are found in up to $40 \%$ of cases of familial melanoma (Hussussian et al. 1994). CDKN2A encodes completely distinct proteins from two alternatively spliced transcripts, p16 ${ }^{\mathrm{INK} 4 \mathrm{a}}$ (inhibitor of kinase a) and $\mathrm{p} 14^{\mathrm{ARF}}$ (alternative reading frame). p16 ${ }^{\text {INK4a }}$ inhibits CDK4 and CDK6, thus preventing phosphorylation of the retinoblastoma tumor suppressor RB1 and blocking E2F transcriptional activation. p14 ${ }^{\mathrm{ARF}}$ inhibits human double minute 2 (HDM2), leading to p53 stabilization and increased expression of its target gene, CDKN1A.

The second high-risk CM susceptibility gene, for which only a few families have been reported to carry mutations, is CDK4. Germline mutations in CDK4 contain arginine at position 24 instead of cysteine (p.R24C) or histidine (p.R24H) and prevent its interaction with p16 ${ }^{\text {INK4A }}$ (Zuo et al. 1996).

Additionally, germline inactivation of $R B 1$ predisposes carriers to $\mathrm{CM}$, at least those who survive their retinoblastoma, a rare cancer of the eye (Fletcher et al. 2004). Hence, multiple mechanisms operate in CM to overcome the RBdependent G1 arrest, thereby favoring improper progression from G1 to $S$ phase and allowing uncontrolled cell proliferation. Furthermore, RB plays a pivotal role in the induction and maintenance of senescence. Therefore, all of the above-described alterations in the RB pathway favor senescence bypass, which is a mandatory step toward melanoma progression (Sherr and McCormick 2002).

In recent years, other high-risk genes have been discovered and may explain $\sim 1 \%-2 \%$ of familial CM. Although not discussed in detail here, these candidates are associated with genes implicated in DNA repair, such as the gene encoding BRCA-1-associated protein (BAP1) (Wiesner et al. 2011), and in telomere maintenance, including POT1, $A C D$, TERF2IP, and TERT (telomerase reverse transcriptase) (for review, see Aoude et al. 2015). Thus, the process of senescence appears to be central to the development of melanoma because the melanoma susceptibility genes mentioned above are also linked to cellular senescence.

In addition to these rare but highly penetrant mutations, which confer a high risk of CM, more common 
single-nucleotide polymorphisms (SNPs) represent low to intermediate CM susceptibility alleles. Two susceptibility genes with medium penetrance, melanocortin-1 receptor $(M C 1 R)$ and microphthalmia-associated transcription factor $(M I T F)$, have also been implicated in the risk of CM. $M C 1 R$ encodes the melanocyte-stimulating hormone receptor that acts by activating the cyclic adenosine monophosphate/protein kinase A (cAMP/PKA) pathway to control MITF expression and the pigmentation process (Bertolotto et al. 1998a, b). MC1R variants reduce the ability to stimulate eumelanin production, causing melanocytes to favor pheomelanin synthesis, and are responsible for the red hair color (RHC) phenotype (Schioth et al. 1999/. Furthermore, MC1R interacts with PTEN (phosphatase and tensin homolog) and protects it from degradation, allowing moderation of the downstream phosphatidylinositol-3-kinase (PI3K) signaling pathway. Interestingly, the MC1R RHC variants do not interact with PTEN (Cao et al. 2013) and therefore might favor sustained activation of the PI3K pathway, which supports senescence bypass in the context of $\mathrm{BRAF}^{\mathrm{V} 600 \mathrm{E}}$ (brain rapidly accelerated fibrosarcoma V600E) melanoma cells (Dankort et al. 2009; Vredeveld et al. 2012). Moreover, $\mathrm{MC1R}$ is also linked to DNA repair mechanisms (for review, see Herraiz et al. 2017). Therefore, alterations of MC1R functions in photoprotective melanin synthesis, DNA repair, and senescence bypass by RHC variants might explain the increased risk of melanoma in carriers.

$M I T F$ is a master regulator gene of melanocyte development and differentiation (Steingrimsson et al. 2004) and has also been associated with melanoma development and progression (Garraway et al. 2005). Recently, we and others identified a recurrent germline mutation in MITF (p.E318K) that predisposes carriers to melanoma (Bressac-de-Paillerets et al. 2002; Bertolotto et al. 2011; Yokoyama et al. 2011; Ghiorzo et al. 2013). Additionally, variants of pigmentation genes $(M C 1 R, A S I P, M A T P$, TYRP1, SLC45A2, and OCA2) or nonpigmentation genes (MTAP, PARP1, and CASP8) represent low penetrance mutations (for review, see Aoude et al. 2015). Although both medium to low penetrance genes per se have a weak impact on melanoma predisposition, they can act as modifiers of high-risk genes and somatic mutations and can dramatically impact melanoma development.

UM also occurs in a familial setting in $1 \%-2 \%$ of cases (Krygier et al. 2001). Major risk factors include fair skin and light eye color, a large number of dysplasic nevi, the presence of oculodermal melanocytosis or nevus of Ota, variation in the HERC2/OCA2 region that influences the human pigmentation phenotype (Sturm and Larsson 2009; Ferguson et al. 2016), and infrequent mutations in the tumor predisposition syndrome gene BAP1 (Harbour et al. 2010; Gupta et al. 2015). UM patients have a significantly increased risk of CM (Scelo et al. 2004), but the mechanisms underlying this risk remain unexplained. Variants in MC1R that were shown to influence the quality and quantity of melanin production do not play a role in the susceptibility to developing UM (Metzelaar-Blok et al. 2001; Hearle et al. 2003a,b; Vajdic et al. 2003). Likewise, current data argue against an important role of the
CDKN2A gene in UM susceptibility. However, methylation of the $p 16^{I N K 4 A}$ gene and inhibition of its expression or cyclin D overexpression have been reported (van der Velden et al. 2001). Moreover, although RB and p53 are infrequently mutated in UM, their respective pathways may be functionally inactivated (Brantley and Harbour 2000a, b). Tumor rarity and the few population-based studies restrict robust conclusions regarding potential risk factors for conjunctival melanoma.

\section{Acquired risk factors: genetic alterations}

\section{$C M$}

Recently, Bastian (2014) updated the classification of melanoma by integrating the huge amount of data revealing the genetic alterations in melanoma in association with specific clinical or histopathological characteristics and different environmental factors such as UVR, thereby providing an integrated taxonomy of melanocytic neoplasia. These acquired genetic alterations are depicted below (Fig. 1). In this review, we mainly refer to driver mutations, which, by definition, confer a selective growth advantage to the cells in which they occur (Vogelstein et al. 2013).

Whole-genome and whole-exome sequencing of large CM series confirmed the presence of $B R A F(50 \%)$ and NRAS $(20 \%-25 \%)$ mutations that had been identified previously using candidate gene approaches and also revealed a panel of novel frequent somatic genetic alterations that activate oncogenes or inactivate tumor suppressor genes (Berger et al. 2012; Hodis et al. 2012; Krauthammer et al. 2012; Network 2015).

The Ras family consists of the three isoforms HRAS, $N R A S$, and KRAS, each encoding a membrane-localized small GTPase that triggers the activation of RAF family serine/threonine kinases (ARAF, RAF1, and BRAF) and the downstream ERK (extracellular regulated kinase) pathway. The ERK pathway plays a very important role in tumor development, particularly in melanoma development, because it is involved in the control of several key cellular processes, including migration, survival, and proliferation (Dhillon et al. 2007).

Somatic NRAS mutations are concentrated within two hot spots that occur most frequently in exon 1 (leading to the substitution of glycine at position 12 [p.G12V]) or exon 2 (leading to the substitution of glutamine at position $61[\mathrm{Q} 61 \mathrm{~K} / \mathrm{L} / \mathrm{R}])$ (Platz et al. 2008). The mutations prevent GTP (guanosine triphosphate) hydrolysis and lock NRAS in a permanently active state that continually activates downstream effectors such as BRAF.

Ninety percent of the hot spot somatic mutations in the serine/threonine protein kinase $B R A F$ cause the amino acid substitution p.V600E in exon 15 (Davies et al. 2002). This mutation disrupts the normal intramolecular interaction that holds BRAF in an inactive conformation, thereby constitutively activating BRAF (Garnett and Marais 2004). Mutations in BRAF and NRAS occur in a mutually exclusive pattern.

Remarkably, among the new recurrent driver mutations that have been identified, two genes, neurofibromin 


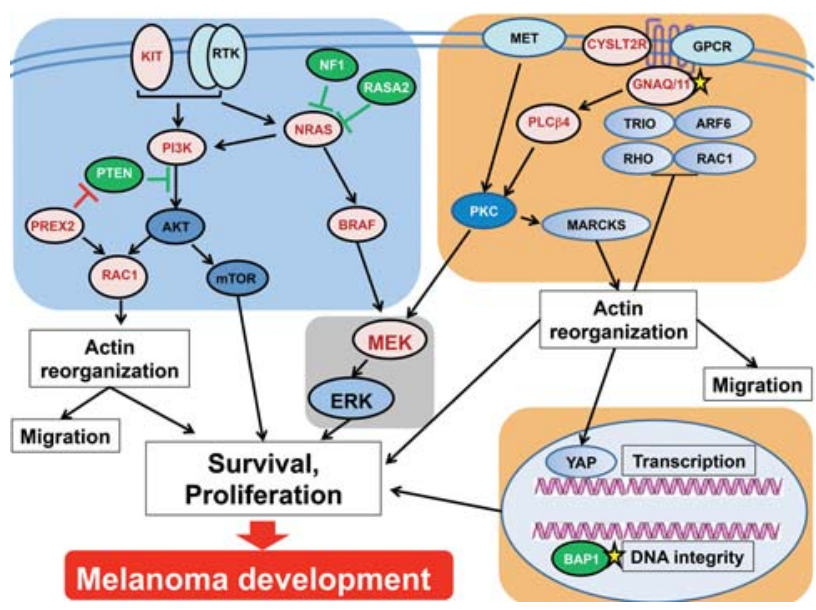

Figure 1. Main genetic and signaling pathway alterations in UMs and CMs. Signaling modules implicated in CMs (blue box), UMs (orange boxes), and both lesions (gray box). Gain-offunction (red) and loss-of-function (green) mutations are indicated as well as genes mutated in both UM and CM (yellow star). In $\mathrm{CM}$, growth factor binding to receptor tyrosine kinase or mutations trigger the activation of the RAS (Rous sarcoma)-BRAFMEK-ERK (extracellular regulated kinase) and/or PI3K-AKT (protein kinase B)-mTOR signaling cascades. In UM, ligand binding to G-protein-coupled receptors (GPCRs), among which is CYSLTR2 (cysteinyl leukotriene receptor 2), enables GNAQ/11 [guanine nucleotide-binding protein $\mathrm{G}(\mathrm{q})$ subunit $\alpha /$ guanine nucleotide-binding protein subunit $\alpha-11$ ] to signal to downstream effectors such as ARF6 (ADP-ribosylation factor 6), TRIO, and PLC $\beta$ (phospholipase $C \beta$ ) and triggers activation of multiple signaling pathways. These pathways include the TRIO-RHO-RAC (Ras-related C3 botulinum toxin)-YAP (yes-associated protein) cascade, which is involved in actin cytoskeleton reorganization and PKC (protein kinase C)-ERK, which controls cell proliferation. Moreover, BAP1, which is lost in a large proportion of UM, controls DNA integrity, proliferation, and survival of melanoma cells, the dysregulation of which is involved in transformation. Note that GNAQ/11 and BAP1 are also affected to a lesser extent in CMs.

1 (NF1) and RAS (Rous sarcoma) p21 protein activator 2 (RASA2), which are mutated in $\sim 15 \%$ and $5 \%$ of CM, respectively, function as RAS-GAP. NF1 and RASA2 undergo loss-of-function mutations that increase the level of active RAS-GTP and the activation of downstream ERK and PI3K signaling pathways (Hodis et al. 2012; Krauthammer et al. 2012, 2015; Arafeh et al. 2015).

Mutations in MAP2K1 (mitogen-activated protein kinase kinase 1; also called MEK1) and MAP2K2 (MEK2), which function downstream from BRAF, have also been identified in $8 \%$ of cases and confer resistance to MEK and BRAF inhibitors (Emery et al. 2009; Nikolaev et al. 2011; Villanueva et al. 2013).

Altogether, mutations in the genes discussed above are found in $>80 \%$ of CM patients and result in constitutive activation of the ERK signaling pathway.

It is noteworthy that these driver mutations do not necessarily translate into tumor induction, since NRAS and BRAF mutations are frequently found in congenital (Bauer et al. 2007) and common acquired (Pollock et al. 2003) nevi, respectively. The nevus is thought to be a pretumoral lesion that displays blunted progression toward melanoma by senescence (Michaloglou et al. 2005; Denoyelle et al. 2006; Zhuang et al. 2008). Additional epigenetic or genetic alterations of CDKN2A or in the PI3K pathway are required to allow melanoma development (Ackermann et al. 2005; Dankort et al. 2009; Dhomen et al. 2009; Vredeveld et al. 2012). Consistent with these findings, recurrent somatic mutations in $B R A F$ are frequently associated with a deletion in $\operatorname{PTEN}(7 \%)$ and/or $C D K N 2 A$, which also occurs at a somatic level in a large proportion of melanomas $(30 \%)$. A recent study from our laboratory supports this idea, demonstrating that the MITF $^{\mathrm{E} 318 \mathrm{~K}}$ variant functions by inhibiting cell cycle inhibitors, including $\mathrm{p} 16^{\mathrm{INK} 4 \mathrm{~A}}$, to delay the implementation of $\mathrm{BRAF}^{\mathrm{V} 600 \mathrm{E}}$-mediated oncogene-induced senescence (OIS) (Bonet et al. 2017).

Hence, the PI3K pathway and CDKN2A represent important modulators of ERK-dependent melanoma tumor progression (Tsao et al. 2004; Janku et al. 2011; Shull et al. 2012) by favoring OIS bypass and CM development.

$\mathrm{PI} 3 \mathrm{~K}$ also plays an instrumental role in melanoma. PI3K activation stimulates the downstream kinase AKT (protein kinase B) and engages pleiotropic cellular responses, including the regulation of cell motility, survival, and proliferation. In CM, the PI3K pathway can be activated as a consequence of constitutive NRAS activation and activating mutations or amplification in the catalytic subunit of PI3K (PIK3CA 4\% and PIK3CG 3\%) (http://cbioportal.org; Janku et al. 2011; Shull et al. 2012) as well as AKT (1\%$4 \%$ ) (Davies et al. 2008). However, the inactivation of PTEN that occurs in $20 \%-30 \%$ of CM cases due to mutations $(8 \%)$, deletion $(6 \%)$, or epigenetic silencing is the main cause of PI3K pathway activation (Wu et al. 2003; Mirmohammadsadegh et al. 2006). Supporting the key role of the PI3K pathway in melanoma, mutations in other effectors of the PI3K pathway have also been reported. The AKT family can activate $\beta$-catenin, another factor that is important for melanoma formation, which can also be altered by mutations $17 \%$ in The Cancer Genome Atlas [TCGA] cohort) (for reviews, see Larue and Delmas 2006; Bennett 2008). $\beta$-Catenin activation can impair OIS (Damsky et al. 2011) and, through p16 ${ }^{\text {INK4A }}$ inhibition, promote senescence evasion and immortalization in mouse melanocytes (Delmas et al. 2007). PTEN loss can also act through a PI3K-independent and caveolin-dependent pathway to trigger nuclear $\beta$-catenin shuttling, p16 ${ }^{\mathrm{INK} 4 \mathrm{~A}}$ repression, and senescence bypass (Conde-Perez et al. 2015).

Also operating downstream from AKT, the mTOR signaling pathway is commonly affected $(>15 \%$ of melanoma cases) by mutations in MTOR, TSC1, TSC2, RICTOR, and $R P T O R$, as observed in the TCGA melanoma cohort (http ://cbioportal.org; Cerami et al. 2012; Gao et al. 2013). However, further studies are required to determine their potential contribution to CM development.

Mutations in RAC1 (Ras-related C3 botulinum toxin substrate 1), one of the key targets/effectors of PI3K, occur at a frequency of $\sim 4 \%-7 \%$. RAC1 belongs to the Rho family of genes that includes $>20$ members and encodes GTP 
hydrolases, which are known to affect the cell cytoskeleton and motility. Additionally, aberrant activation of PREX2 (phosphatidylinositol-3,4,5-trisphosphate-dependent RAC exchange factor 2), a member of the DBL family of guanine nucleotide exchange factors (GEFs) specific for RAC1, has been identified in $14 \%$ of cases. PREX2 has also been reported as a PTEN-interacting protein and negative regulator of its phosphatase activity (Fine et al. 2009; Berger et al. 2012). However, whether PREX2 is a true melanoma driver gene has been questioned recently and thus remains to be formally determined (Horrigan et al. 2017).

Of note, $50 \%$ of CMs harbor genetic alterations in genes encoding PTEN, catalytic subunits of PI3K, AKT, and $R A C 1$, which function in the PI3K signaling pathway.

CM can also display mutations or amplification in the transmembrane receptor tyrosine kinase KIT $15 \%-8 \%$ of cases). These alterations appear to be more frequent in acral, mucosal, or lentigo maligna melanomas (Curtin et al. 2006; Beadling et al. 2008). They lead to stem cell factor (SCF/KIT ligand)-independent activation of KIT and its associated downstream signaling cascade, including MAPK/ERK, PI3K, and phospholipase C (Carvajal et al. 2011; Allegra et al. 2014).

Most importantly, whole-genome/exome studies of CM have also led to the identification of frequent mutations in other genes, including the tumor suppressor gene TP53 (19\%), the subunit of the PBAF chromatin remodeling complex ARID2 (7\%), or the serine/threonine phosphatase PPP6C $(12 \%)$, which is involved in the control of the cell cycle. The presence of recurrent somatic mutations in the TERT promoter $(\sim 75 \%$ of metastases and $33 \%$ of primary lesions) has been reported in CM (Patel et al. 2016). All of these mutations might also function to inhibit or delay OIS. A large panel of other (not discussed in this review), less frequently mutated genes has been revealed, all of which might represent CM drivers or modifying genes and are potential targets for new therapeutic approaches (for reviews, see Bertolotto 2013; Shtivelman et al. 2014; Zhang et al. 2016; Weyden et al. 2017).

Thus, this mutational landscape emphasizes the importance of the ERK and PI3K signaling pathways as well as the bypass of senescence in CM development, progression, and resistance to therapies.

\section{$U M$}

Similar large-scale whole-genome and whole-exome sequencing studies performed in UM validated previously occurring mutations mainly in GNAQ [guanine nucleotide-binding protein $G(q)$ subunit a] or GNA11 (guanine nucleotide-binding protein subunit a-11) (83\%), BAP1 $(40 \%)$, SF3B1 (splicing factor $3 B$, subunit 1) $(20 \%)$, and EIF1AX leukaryotic translation initiation factor $1 A, X$ linked) (8\%) (Decatur et al. 2016; Johansson et al. 2016; Moore et al. 2016). These studies also pinpointed other driver genes that provide a basis for identifying molecular frameworks for the design of therapeutic strategies.

The Ga subunit of the heterotrimeric $\mathrm{G}$ proteins (GNAQ) or its paralog (GNA11) share $90 \%$ sequence homology and represent the most frequently mutated genes in UM. Ninety-seven percent of the hot spot somatic mutations cause the amino acid substitution p.Q209L (the most common) or p.Q209P in exon 5. The other $3 \%$ of mutations cause a p.R183C amino acid change in exon 4. The Q209 mutation triggers a complete loss of intrinsic GTPase activity and renders GNAQ/GNA11 constitutively active to prolong its downstream signaling. In contrast, the R183 mutation is weakly activating because it causes only a partial loss of intrinsic GTPase activity. The Q209 and R183 mutations occur in a mutually exclusive pattern in UM. Mutations in GNAQ or GNA11 are found in $45 \%$ and $32 \%$ of primary UM, respectively, and $22 \%$ and $57 \%$ of metastatic UM, respectively /Onken et al. 2008; Van Raamsdonk et al. 2009, 2010). Although differences between GNAQ and GNA11 signaling have not been elucidated, these findings suggest that GNA11 mutant tumors have a greater tendency to metastasize. GTP-GNAQ/11 and $\beta-\gamma$ subunits transfer the signal from the receptor to downstream effectors that stimulate diverse signaling pathways, including the MAPK pathway, possibly via DAG (diacylglycerol)-mediated activation of protein kinase $\mathrm{C}$ (PKC) isoforms, the ADPribosylation factor 6 (ARF6)-TRIO-RHO/RAC implicated in cytoskeletal organization, and yes-associated protein 65 (YAP), a key component of the HIPPO signaling pathway (Feng et al. 2014; Yu et al. 2014; Yoo et al. 2016). ARF6 acts as a proximal node of oncogenic GNAQ signaling and contributes to activation of the downstream pathways (Yoo et al. 2016). Of note, no ARF6 mutations have been discovered to date in UM or other cancers.

The importance of GNAQ in UM is highlighted by the observation that mutations in upstream regulators and downstream effectors were identified recently. Cysteinyl leukotriene receptor 2 (CYSLTR2) is a seven-transmembrane G protein-coupled receptor (GPCR) and a member of the rhodopsin-like family that responds to purinergic or pyrimidinergic nucleotides (P2Ys). As a member of the GPCR family, CYSLTRs signal through activation of GNAQ/11 (Mong et al. 1988). Recurrent p.L129Q as well as p.R136H mutations in CYSLTR2 have been discovered in UM patients (Moore et al. 2016). Only p.L129Q CYSLTR2, which favors the transition toward an active conformation, is oncogenic. CYSLTRs are activated by cysteine-containing leukotrienes (LTC4, LTD4 [leukotriene D4], and LTE4), which are lipid mediators and robust inflammatory mediators. LTC4 and LTD4 are potent mitogens of normal human epidermal melanocytes (Morelli et al. 1989). Leukotrienes also have roles in multiple diseases, including cancer. LTD4, a CYSLTR2 agonist, facilitates cell survival and proliferation of intestinal epithelial cells through $\beta$-catenin activation (Mezhybovska et al. 2005). LTD4 also regulates the survival and migration of human colon cancer cells by regulation of an anti-apoptotic member of the BCL2 family and activating integrin, respectively (Massoumi et al. 2003; Wikstrom et al. 2003a,b). Collectively, these data are consistent with a role for LTD4 in cancer, including UM. Additionally, in response to a pathobiological event, CYSLTR2 can mediate an increase in vascular 
permeability in some tissues (Beller et al. 2004), a process that might contribute to UM blood dissemination.

Among the downstream effectors of GNAQ/11 are members of the phospholipase C (PLC) family (mainly PLC $\beta$ ), which hydrolyzes PIP2 (phosphatidylinositol-2 phosphate) to generate IP3 (inositol trisphosphate) and DAG. IP3 triggers the release of calcium ions from the endoplasmic reticulum, whereas DAG activates the PKC signaling cascade. A recurrent mutation in $P L C B 4$, which encode p.D630Y, was identified recently in UM patients (Johansson et al. 2016; Moore et al. 2016). This mutation is located in the Y domain of the highly conserved catalytic core of PLCB4, which is activated by direct interaction with GNAQ (Lyon and Tesmer 2013). A novel mutation in PLCB3, encoding p.K898N, has also been discovered (Johansson et al. 2016). Again, this mutation lies in a domain, the CTD linker, that is linked to GNAQ activation (Lyon and Tesmer 2013). However, the role of $P L C B 3$ as a UM driver gene remains to be demonstrated. Mutations in CYSLTR2, GNAQ, GNA11, and PLCB4 are mutually exclusive, suggesting that they operate in the same pathway.

UM metastases are also associated with inactivating somatic mutations in BAP1 in $\sim 80 \%$ of cases, which generally cause protein truncations and are associated with a poor prognosis (Harbour et al. 2010). BAP1 is a chromatin-associated deubiquitinase that induces poly (ADP-ribose)-dependent recruitment of the polycomb deubiquitylase complex PR-DUB (polycomb-repressive deubiquitylase) to sites of DNA damage and is required for efficient assembly of the homologous recombination (HR) factors BRCA1 and RAD51 (An et al. 2014). Consequently, its mutation impairs its function in DNA double-strand break repair (Ismail et al. 2014). Moreover, BAP1 impacts histone $\mathrm{H} 2 \mathrm{~A}$ ubiquitination, regulates transcriptional programs that support the maintenance of melanocytic cell identity, and blocks their transition toward a stem-like phenotype (Landreville et al. 2012; Matatall et al. 2013).

Dysregulation of the activity of two other genes, SF3B1 and EIF1AX, has prognostic value in UM.

EIF1AX is a component of the 43S preinitiation complex (PIC), which mediates the recruitment of the small $40 \mathrm{~S}$ ribosomal subunit to the $5^{\prime}$ cap of messenger RNAs. It is not clear how these mutations might promote cancer, but the dysregulation of mRNA translation is a frequent feature of neoplasia (Bhat et al. 2015). Recurrent mutations in EIF1AX are found mainly in low metastatic risk tumors with no ciliary body involvement (Furney et al. 2013; Martin et al. 2013; Johansson et al. 2016), meaning they are associated with a good prognosis.

SF3B1 encodes a core component of the U2 small nuclear ribonucleoprotein (snRNP) complex of the spliceosome involved in $3^{\prime}$ splice site recognition during RNA splicing (Furney et al. 2013; Zhang and Manley 2013; Alsafadi et al. 2016). Alternative splicing contributes to structural transcript variation and proteome diversity, a process involved in disease progression (Sveen et al. 2016). The SF3B1 missense hot spot mutations (p.R625C, p.R625H, p.K666T, and p.K700E) are associated with low risk for metasta- sis (Furney et al. 2013; Harbour et al. 2013; Martin et al. 2013; Alsafadi et al. 2016). Recently, Harbour's group (Field et al. 2016a,b) has shown that SF3B1 mutations often occur in tumors expressing the oncogene preferentially expressed antigen in melanoma (PRAME), which is an independent biomarker for metastasis. PRAME expression appears to be inversely associated with EIF1AX mutations.

$B A P 1, S F 3 B 1$, and EIF1AX mutations are almost mutually exclusive with each other (Martin et al. 2013; Decatur et al. 2016; Royer-Bertrand et al. 2016; Yavuzyigitoglu et al. 2016).

Finally, whole-genome/exome studies have revealed somatic missense or truncating mutations in a panel of other genes, but their roles in UM remain to be elucidated (Johansson et al. 2016; Royer-Bertrand et al. 2016).

Interestingly, GNAQ/11 mutations have also been identified in $\sim 5 \%$ of skin melanomas, but oncogenic driver mutations similar to those identified in UM (Q209P or Q209L) are found in only $\sim 2 \%$ of CM cases (http ://cbioportal.org). One Q209 mutation was found in a CM from chronically sun-damaged skin among the 74 samples analyzed (Van Raamsdonk et al. 2010). Furthermore, $P L C B 4$ is recurrently mutated with a high frequency $(21 \%-28 \%)$ in CM (Wei et al. 2011; Hodis et al. 2012; The Cancer Genome Atlas Network 2015; Krauthammer et al. 2015). However, none of these mutations is identical to those found in UM, and no hot spot mutations can be found, indicating that they are unlikely to function as driver mutations. It should be noted that TRIO is also affected in $10 \%$ of CM. In $5 \%$ of the cases, these alterations seem to be passenger mutations, but, in the remaining $5 \%$, TRIO is amplified (http://cbioportal.org) and might participate in CM development. Nevertheless, elucidation of the role of GNAQ/11 and its downstream effectors, PLCB4 and TRIO, in CM requires additional investigation.

Finally, BAP1 is affected in $40 \%$ of UM cases, and the majority of the alterations is truncating mutations. In contrast, BAP1 is affected in 3\% of CM cases, but truncation mutations are a rare event (http://cbioportal.org).

Little is known about the genetic perturbations in conjunctival melanomas. Nevertheless, primary and metastatic conjunctival melanomas harbor BRAF, mainly p. V600E (27\%-50\%) and NRAS p.Q61K/R/L (18\%) mutations (Griewank et al. 2013). Mutations in the promoter of TERT are also detected in conjunctival melanomas $(32 \%)$ but not in UM (Griewank and Murali 2013). They harbor a UV signature identical to those found in CM that mediates increased expression of TERT by generating new binding motifs for Ets transcription factors (Horn et al. 2013). Therefore, from a genetic perspective, conjunctival melanoma seems to have more similarities to $\mathrm{CM}$ than to UM.

\section{Cytogenetic alterations}

Before the use of deep sequencing approaches, the genetic modifications in CM and UM were determined by cytogenetic studies. Comparative genomic hybridization was 
used to map copy number abnormalities. The frequent chromosomal aberrations are reported below.

CM exhibits complex cytogenetic alterations (for review, see van den Bosch et al. 2010). They are characterized by frequent losses involving chromosomes 4, 5, 6q, $8 \mathrm{p}, 9 \mathrm{p}, 10 \mathrm{q}, 11 \mathrm{q}, 12 \mathrm{q}, 14,15,16,21$, and 22, whereas gains most often occurred at 1q, 6p, 7, 8q, 18, and 20q (Bastian et al. 1998; Pirker et al. 2003). It is worth mentioning the rearrangement in chromosome 1 , where NRAS $11 \mathrm{p} 13$ region) and $A K T 3$ (1q44 region) are located; of chromosome 7, harboring the $B R A F$ gene (7q34); and of chromosome 9 with $C D K N 2 A(9 \mathrm{p} 21)$.

In UM, chromosomal aberrations include mainly monosomy $3(50 \%)$ as well as $6 \mathrm{p}$ and $8 \mathrm{q}$ gain. UM tumors with monosomy 3 and polysomy $8 \mathrm{q}$ correlate with high metastatic risk and poor prognosis (de Lange et al. 2015; Versluis et al. 2015). Monosomy 3 occurs in $50 \%$ of the analyzed cases, is rather specific for UM because this chromosomal aberration is rarely encountered in other cancer types, and is the most widely used predictor of UM metastatic disease (van den Bosch et al. 2012). Chromosome 3 likely hosts tumor suppressor genes. One of the most studied is BAP1. Conversely, genes that can contribute to tumor progression are located in the $8 \mathrm{q}$ region, such as MYC (8q24) (Muller et al. 2010) or ASAP1 (DDEF1; 8q24) (Meyer and Penn 2008). Interestingly, ArfGAP with the SH3 domain, ankyrin repeat, and $\mathrm{PH}$ domain (ASAP1) is a GTPase-activating protein for ARF1 as well as ARF6 (Furman et al. 2002). Although the gain of chromosome $8 \mathrm{q}$ is also found in $25 \%$ of $\mathrm{CM}$, co-occurrence of both monosomy 3 and the gain of $8 \mathrm{q}$ is rare in $\mathrm{CM}$. UM tumors with such a 6 p gain are less likely to show chromosome 3 loss and are associated with better survival. Moreover, chromosome 10, which contains PTEN, is also altered in UM $(27 \%)$ but to a lower frequency compared with CM (60\%). PTEN down-regulation seems to occur in UM lesions with high genomic instability, supporting a role late in tumor progression (Ehlers et al. 2008).

Several other DNA copy number alterations, including the gain of $1 \mathrm{q}$ or loss of $8 \mathrm{p}, 1 \mathrm{p}$, and $6 \mathrm{q}$, also characterize UM (Aalto et al. 2001; Trolet et al. 2009; Damato et al. 2010; Royer-Bertrand et al. 2016).

Collectively, CM tumors display very complex karyotypes that cannot be used to provide valuable prognostic information. In contrast, UM presents a relatively "simple" karyotype, with recurrent chromosomal anomalies, which has valuable prognostic impact for patients. Consequently, high-risk patients may benefit from accurate surveillance (including of the liver, which is the most common metastatic site) or enter clinical trials investigating adjuvant therapy.

\section{The gene expression program}

Cytological and histochemical methods have long been recognized as useful for analyzing the intertumor and intratumor heterogeneity in CM. More recently, highthroughput approaches (DNA arrays and RNA sequencing) have confirmed that CM displays a high degree of intertumor heterogeneity even in the same individual (Kemper et al. 2015). Intratumoral heterogeneity was validated at the single-cell level (Ennen et al. 2015; Tirosh et al. 2016). Tumor phenotypic heterogeneity may be caused by genetic heterogeneity but also may be generated by the impact of the tumor microenvironment without any requirement for new or additional genetic events. Understanding and deciphering tumor heterogeneity remain a challenge to cancer therapy.

CM cells can be classified into at least two major states; i.e., proliferative and invasive (Hoek et al. 2008). A model derived from these findings, the "phenotype-switching" model, predicts that melanoma cells are plastic and may switch between these two states to generate intratumoral heterogeneity (Hoek and Goding 2010). This model postulates that high MITF activity triggers a differentiation phenotype, whereas low MITF activity is associated with mesenchymal transition and an invasive phenotype (Carreira et al. 2006; Cheli et al. 2011; Ohanna et al. 2011). More recently, a larger gene repertoire linked to activation of the HIPPO-YAP pathway (Muller et al. 2014; Verfaillie et al. 2015) and metabolic stress responses (Falletta et al. 2017) has been established as an indicator of this plasticity. Previous reports have demonstrated that phenotype switching toward a more mesenchymal cell state is associated with intrinsic and acquired resistance to targeted therapies (Johannessen et al. 2013; Konieczkowski et al. 2014; Muller et al. 2014; Van Allen et al. 2014). Melanoma phenotype switching also negatively impacts immune checkpoint blockade and impairs the efficiency of immunotherapy (Landsberg et al. 2012; Riesenberg et al. 2015; Falletta et al. 2017).

Intertumor heterogeneity has also been described in UM. Molecular analyses classify UM into two prognostically significant molecular classes (Onken et al. 2004, 2006, 2010a). Class 1 UM tumors, which have been further divided into well-defined class $1 \mathrm{~A}$ and class $1 \mathrm{~B}$, retain a differentiated melanocytic phenotype and have a low to intermediate metastatic risk, respectively. EIF1AX and SF3B1 are associated with class 1, with SF3B1 showing a particular association with class $1 \mathrm{~B}$ (Harbour et al. 2013). Class 2 UM tumors exhibit a dedifferentiated stem cell-like and epithelioid phenotype that is associated with monosomy of chromosome 3 and a high metastatic risk (Field and Harbour 2014). Interestingly, the class 2 expression program is mainly a consequence of monosomy 3 and loss of function of BAP1. Indeed, depletion of BAP1 in cultured class 1 UM cells induced a loss of the melanocyte differentiation markers and the acquisition of a class 2 gene expression profile (Landreville et al. 2012; Matatall et al. 2013).

The gene expression profile capable of distinguishing class 1 and class 2 primary UM has been further restricted to a set of 12 genes (Table 2). This set has been shown to be more accurate than all other clinical and pathologic factors, such as chromosome 3 status (monosomy 3), cytopathology, and tumor size, in predicting the development of metastases (Onken et al. 2010b).

Importantly, coexistence of the spindle and epithelioid cells in some UM tumors revealed by histopathological 
Pandiani et al.

Table 2. Gene expression signature in UM

\begin{tabular}{|c|c|c|c|c|c|}
\hline $\begin{array}{l}\text { Gene } \\
\text { symbol }\end{array}$ & Gene name & $\begin{array}{l}\text { Genomic } \\
\text { location }\end{array}$ & $\begin{array}{l}\text { Direction } \\
\text { in class } 2 \\
\text { primary UM }\end{array}$ & Function & $\begin{array}{l}\text { Correlation with } \\
\text { survival in } \mathrm{CM} ; \\
P \text {-value }\end{array}$ \\
\hline$C D H 1^{*}$ & E-cadherin & $16 \mathrm{q} 22.1$ & Up & $\begin{array}{l}\text { Cell-cell adhesion, } \\
\text { mobility and } \\
\text { proliferation of epithelial } \\
\text { cells }\end{array}$ & No \\
\hline ECM1* & Extracellular matrix protein 1 & $1 \mathrm{q} 21.2$ & Up & $\begin{array}{l}\text { Cell adhesion, cell-to-cell } \\
\text { communication and } \\
\text { differentiation }\end{array}$ & No \\
\hline$R A B 31^{*}$ & $\begin{array}{l}\text { RAB31, member RAS oncogene } \\
\text { family }\end{array}$ & $18 \mathrm{p} 11.22$ & Up & $\begin{array}{l}\text { Regulator of vesicle } \\
\text { trafficking }\end{array}$ & No \\
\hline$H T R 2 B^{*}$ & $\begin{array}{l}\text { 5-hydroxytryptamine (serotonin) } \\
\text { receptor } 2 \mathrm{~B}\end{array}$ & $2 \mathrm{q} 37.1$ & Up & Receptor & Positive $(P=0.044)$ \\
\hline$I D 2^{*+}$ & Inhibitor of DNA binding 2 & $2 \mathrm{p} 25.1$ & Down & Transcriptional regulator & Positive $(P=0.008)$ \\
\hline EIF1B* & $\begin{array}{l}\text { Eukaryotic translation initiation } \\
\text { factor } 1 \mathrm{~B}\end{array}$ & $3 \mathrm{p} 22.1$ & Down & $\begin{array}{l}\text { Poly(A) RNA binding and } \\
\text { translation initiation } \\
\text { factor activity }\end{array}$ & No \\
\hline FXR $1^{*}$ & $\begin{array}{l}\text { Fragile } \mathrm{X} \text { mental retardation } \\
\text { autosomal homolog } 1\end{array}$ & $3 \mathrm{q} 26.33$ & Down & $\begin{array}{l}\text { Nucleic acid binding and } \\
\text { RNA binding }\end{array}$ & No \\
\hline$L M C D 1^{*}$ & LIM and cysteine-rich domains 1 & $3 \mathrm{p} 25.3$ & Down & $\begin{array}{l}\text { Protein-protein } \\
\text { interactions, } \\
\text { Transcriptional regulator }\end{array}$ & No \\
\hline $\mathrm{ROBO}^{*+}$ & $\begin{array}{l}\text { Roundabout, axon guidance } \\
\text { receptor } 1\end{array}$ & $3 \mathrm{p} 12.3$ & Down & Receptor & No \\
\hline$S A T B 1^{*}$ & SATB homeobox 1 & $3 \mathrm{p} 24.3$ & Down & Transcriptional regulator & Positive $(P=0.046)$ \\
\hline MTUS1 ${ }^{*+}$ & $\begin{array}{l}\text { Microtubule-associated tumor } \\
\text { suppressor } 1\end{array}$ & $8 \mathrm{p} 22$ & Down & Signaling & Positive $(P=0.019)$ \\
\hline$L T A 4 H^{*}$ & Leukotriene A4 hydrolase & $12 \mathrm{q} 23.1$ & Down & $\begin{array}{l}\text { Poly(A) RNA binding and } \\
\text { peptidase activity }\end{array}$ & No \\
\hline$A Z G P 1^{\dagger}$ & a-2-glycoprotein 1 , zinc & $7 q 22.1$ & Down & Metabolism & No \\
\hline$E N P P 2^{+}$ & $\begin{array}{l}\text { Ectonucleotide pyrophosphatase/ } \\
\text { phosphodiesterase } 2 \text { (autotaxin) }\end{array}$ & $8 \mathrm{q} 24.12$ & Down & Metabolism & No \\
\hline$E D N R B^{\dagger}$ & Endothelin receptor type B & $13 \mathrm{q} 22.3$ & Down & Receptor & Positive $(P=0.004)$ \\
\hline$G P R 37^{+}$ & $\begin{array}{l}\text { G protein-coupled receptor } 37 \\
\text { (endothelin receptor type B-like) }\end{array}$ & $7 \mathrm{q} 31.33$ & Down & Receptor & No \\
\hline $\operatorname{IL}_{12 R B 2^{+}}$ & Interleukin 12 receptor, $\beta 2$ & 1 p31.3 & Down & Receptor & No \\
\hline$S P P 1^{\dagger}$ & $\begin{array}{l}\text { Secreted phosphoprotein } 1 \\
\quad \text { (osteopontin, bone sialoprotein I, } \\
\text { early T-lymphocyte activation } 1 \text { ) }\end{array}$ & $4 \mathrm{q} 22.1$ & Down & Cell matrix interaction & No \\
\hline$V A M P 8^{+}$ & $\begin{array}{l}\text { Vesicle-associated membrane protein } \\
8 \text { (endobrevin) }\end{array}$ & $2 \mathrm{p} 11.2$ & Down & $\begin{array}{l}\text { Regulator of vesicle } \\
\text { trafficking }\end{array}$ & Positive $(P=0.006)$ \\
\hline
\end{tabular}

List of genes that distinguishes low metastatic risk (class 1 signature) and high metastatic risk (class 2 signature) primary UMs (Onken et al. 2004, 2010b). This list contains the high stringency genes that discriminate class 1 and class 2 genes $(t)$ (fold change $>5$ and false discovery rate $<0.001$ ) (Onken et al. 2006) and the set of 12 genes $(*)$ that has been proposed using a clinically practical PCRbased prognosis assay to identify high-risk patients (Onken et al. 2010b). The direction of the gene expression change in class 2 versus class 1 primary UMs is shown (fourth column). Kaplan-Meier survival analysis for TCGA CM data between the lower and upper quartiles was computed (sixth column). A positive correlation indicates that high gene expression is associated with a good prognosis $(P$-value is given). "No" indicates no correlation. Thus, some genes may have important functions in both UM and CM.

analysis suggests the existence of intratumor heterogeneity in addition to intertumor heterogeneity.

Furthermore, UM metastasis and poor patient outcome are associated with monosomy 3 and the loss of differentiation markers. Remarkably, MITF, which controls melanocyte differentiation (Bertolotto et al. 1998a; Cheli et al. 2010 ) is located in 3p13. Moreover, in skin melanocyte cells, MITF controls the expression of a repertoire of genes involved in DNA repair and replication (Giuliano et al. 2010; Strub et al. 2011). Consequently, one might hypothesize that, in UM, monosomy 3 triggers a reduction of both BAP1 and MITF levels and dampens accurate DNA repair, favoring chromosomal instability and UM progression.

In support of this idea, tumors with disomy 3 contain fewer chromosomal abnormalities, rarely metastasize, and thus are associated with a better survival rate (Onken et al. 2010a; Shields et al. 2011a), which might be explained by the maintenance of MITF. Moreover, MITF haploinsufficiency might favor UM cell switching from a differentiated to undifferentiated metastatic-prone phenotype as observed for $\mathrm{CM}$ and therefore might contribute 
to metastasis development. Collectively, these observations suggest that MITF, which is a nexus in CM pathology, might also play a critical role in UM.

Activation of the transcriptional coactivator YAP, a critical downstream effector of the HIPPO signaling pathway, has been reported in both CM and UM (Feng et al. 2014; Nallet-Staub et al. 2014; Yu et al. 2014). YAP is activated in UM cells downstream from the oncogenic mutation of GNAQ/11 and is required for GNAQ/11-induced tumorigenicity in UM. The YAP-TEAD cascade seems to be implemented in CM cells that have lost MITF and engages in an invasive gene expression program (Verfaillie et al. 2015). These observations suggest that these signaling molecules (MITF, BAP1, and YAP) may represent suitable pharmacological intervention strategies in both tumor types.

\section{Role of UV}

It has long been suspected that UVR exposure was the main environmental risk factor for melanoma. However, the link with melanoma development was not fully understood until recently. Large-scale genomic studies have revealed a higher rate of somatic mutations in CM tumors than in any other tumor types (Lawrence et al. 2013), with a median of 16.8 mutations per megabase (Berger et al. 2012; Hodis et al. 2012; Krauthammer et al. 2012; The Cancer Genome Atlas Network 2015). The highest average mutation rate was observed in chronically sun-damaged skin melanomas (21 per megabase), whereas acral and mucosal melanomas displayed a very low mutational load (The Cancer Genome Atlas Network 2015). These studies have unequivocally provided genomic evidence for a direct mutagenic role of UV light in melanoma pathogenesis. The mutations are predominantly C-to-T or tandem CC-to-TT transitions at specific dipyrimidine sequences, which is the mutational signature of UVB light (Harris 2013), or G-to-T substitutions that might reflect a transversion following oxidative DNA damage (Cheng et al. 1992). Specifically, it was found that $46 \%$ and $9 \%$ of melanoma driver mutations can be attributed to $\mathrm{C}>\mathrm{T}$ or $\mathrm{G}>\mathrm{T}$ mutations, respectively (Hodis et al. 2012). $\mathrm{BRAF}^{\mathrm{V} 600}$ variants, particularly BRAF ${ }^{\mathrm{V} 600 \mathrm{E}}$, which is the main driver gene in melanoma, do not bear the traditional UVB signature mutations. However, sunlight UV is also composed of UVA, which is thought to promote mutagenic lesions through oxidative damage (Besaratinia et al. 2004). Accordingly, DNA lesions induced by UVA exposure resemble the $\mathrm{BRAF}^{\mathrm{V} 600 \mathrm{E}}$ variant mutation (Thomas 2006; Besaratinia and Pfeifer 2008).

From the genomic analyses, it appears that UM tumors have a low mutation burden. Johansson et al. (2016) identified a mean of 10.6 protein-changing mutations per sample, which is consistent with other studies reporting 17 variants per tumor on average (Royer-Bertrand et al. 2016). The mean mutation rate across the UM patient genomes ranges between 0.24 and 0.50 per megabase, which is lower than that of metastatic CM, and the mutation spectrum is not consistent with an UVR signature
(Johansson et al. 2016; Royer-Bertrand et al. 2016), strengthening the lack of UV involvement in UM etiology. However, a C-to-T transition has been described in few cases of UM with a GNAQ/11 R183 mutation, suggesting a possible role of UV in UM.

\section{Comparative biology of UM and CM}

\section{Why are driver mutations different in UM and CM?}

As mentioned above, despite the fact that both CM and UM are derived from melanocytes that originate from neural crest cells, the driver mutation landscape is completely different in these two neoplasms. This difference might be ascribed to the lack of UVR involvement in UM etiology, while UVR is a proven risk factor for CM.

However, the risk of intraocular melanoma is much higher in Caucasians than in African Americans and people with light-colored eyes (Seddon et al. 1990; Vajdic et al. 2002; Tsai et al. 2005), suggesting a possible link to sunlight exposure. Further studies have also proposed a role for short-wavelength blue-light exposure in the etiology of UM (de Lange et al. 2015). Blue light, which is part of the visible light spectrum, reaches deeper into the eye and causes damage to the back of the eye. Although only a part of blue light is harmful, our exposure to it is increasing due to the use of digital devices and modern lighting, which emit blue light. Furthermore, as has been shown for CM, the pheomelanin pigment pathway might contribute to uveal melanomagenesis by a UVR-independent carcinogenic mechanism that depends on oxidative damage (Mitra et al. 2012). Again, this is consistent with the fact that both CM and OM are more common in individuals with pale skin and eyes with light-colored irises in comparison with those with dark-brown skin and eyes (Tsai et al. 2005).

Of note, the main driver mutations-GNAQ/11 ${ }^{\mathrm{Q} 209 L}$ (c.626A > T) and CYSLTR2 ${ }^{\mathrm{L} 129 \mathrm{Q}}$ (c.386T $\left.>\mathrm{A}\right)$ in UM and $B R A F^{V 600 E}$ (c.1799T > A) in CM-display homologous base substitutions, which are not related to UVR, suggesting a converging mutational mechanism.

In addition to understanding the cause of the mutations, it is also important to consider why causative driver mutations are not identical in UM and CM. It should be noted that BRAF and NRAS mutations dominate in lesions arising in an epithelial context such as conjunctival melanoma and CM, excluding blue nevi and blue-nevuslike melanoma. GNAQ/11 mutations are found in melanocytic lesions with an extraepithelial location.

Indeed, GNAQ/11 mutations are not restricted solely to UM but are also found in melanocytic lesions located in leptomeninges (diffuse melanocytosis and meningeal melanomatosis) and dermis (nevus of Ota, blue nevi, and blue nevus-like melanomas)(Van Raamsdonk et al. 2009, 2010; Murali et al. 2012). Most of these lesions arise in the craniofacial region, albeit blue nevi can be found anywhere on the body. A plausible explanation for GNAQ/11 mutation predominance in nonepithelial melanocytes involves subtle geographic variances in the embryonic origin of epithelial and nonepithelial melanocytes. Along the 
embryonic axis, several distinct neural crest populations differ in both their migratory pathways and range of derivatives (Bronner-Fraser 1994). In this context, it has been suggested that nonepithelial melanocytes derive from the cranial rather than the truncal neural crest (Francis et al. 2016), which indicates that although the melanocytes have the same embryonic origin (i.e., the neural crest), they might behave differently as a function of their relative anterior-posterior position (Mayor and Theveneau 2013). However, blue nevi located on the legs, for instance, are unlikely to derive from the cranial neural crest.

Furthermore, it should be noted that epidermal melanocytes interact with epithelial cells, whereas noncutaneous melanocytes interact with mesodermal stroma. The growth and differentiation of epidermal melanocytes appear to be dependent on KIT signaling, whereas noncutaneous melanocytes seem more dependent on the endothelin and hepatocyte growth factor (HGF) signaling pathways (Wilson et al. 2004; Aoki et al. 2009). Therefore, it could be argued that CM and UM acquire the same mutations, but direct cell contact or the paracrine signal produced by the tissue-specific environment might allow proliferation of cells only with specific mutational events and therefore favor selection of specific driver mutations.

Finally, Adameyko et al. (2009) showed that Schwann cells, which also originate from the neural crest and differentiate to form myelin sheaths that surround the mature nerve, constitute another source of melanocytes. A mutation in GNA11 has been reported in a melanotic Schwannoma, a soft tissue benign neoplasm of Schwann cells, which shares histologic features with melanocytic tumors and Schwannomas (Tatsi et al. 2016). Because the mutational spectra of these lesions overlap, it has been hypothesized previously that both cell types could derive from the same developmental mechanism (Van Raamsdonk et al. 2010; Bastian 2014).

\section{Why are gene expression signatures different} in UM and $C M$ ?

In both CM and UM, extensive efforts have been undertaken to identify genes or sets of genes that can predict the clinical outcome of the patients, including metastasis development and survival. As mentioned earlier, the study of numerous primary UM patients has led to a well-defined molecular classification (Table 2). Class 2 UM has the poorest survival prognosis and is characterized by an increase in epithelial markers such as E-cadherin (CDH1) and a loss of differentiation markers such as tyrosinase (TYR) or DCT. For CM, the gene expression signature has been obtained by analysis of metastatic melanoma cell lines or short-term cultures and defines a highMITF/differentiated group endowed with fast proliferation capacity and a low-MITF/poorly differentiated group with highly invasive behavior. The low-MITF CM generally lost epithelial markers such as E-cadherin and gained a mesenchymal phenotype. In these analyses, the use of tumor tissue for UM versus cultured metastatic cells for CM might explain this apparent discrepancy. Of note, analysis of CM tumor tissue also identified a "keratin sub- class" of CM with high expression levels of keratin and epithelial markers (CDH1), indicating a worse prognosis (The Cancer Genome Atlas Network 2015). However, this subclass also displays a high level of differentiation markers, in contrast to reports for primary UM samples. The natures of analyzed UM and CM samples are not similar. Primary lesions are predominant in UM cohorts, while CM tissues are mainly from metastatic samples $(80 \%)$, of which $\sim 50 \%$ are lymph node metastases (The Cancer Genome Atlas Network 2015).

The natural history of metastatic tumor development requires, first, an in situ proliferation phase followed by an invasion phase, allowing melanoma cells to reach metastatic sites. Once at the metastatic site, cells with invasive properties can migrate and colonize other organs or proliferate to promote an increased tumor size, functional failure of the affected organ, and, ultimately, patient death. Therefore, survival will be affected by the ability of tumor cells to implement both the invasive and subsequent proliferative programs. In primary skin melanoma lesions, cells must enable the invasive program, while metastatic cells require only the proliferative program. Accordingly, the gene expression signature associated with poor prognosis might be different if it stems from primary UM lesions or CM metastatic samples.

Despite the invaluable basic information provided by gene expression analyses of melanoma lesions, their translation into clinical advances are currently minimal for CM. Furthermore, primary CM shows a very high level of contamination by keratinocytes that may hinder accurate gene expression profiling. For UM, gene expression profiling has a real clinical impact, perhaps because the analyzed samples are more homogenous.

\section{Why does UM display prominent liver tropism?}

Metastasizing UM displays a tropism to the liver in $90 \%$ of cases, while CM does not demonstrate such a preferential tropism. Indeed, CM cells disseminate to skin or lymph nodes and almost equivalently to the lungs, liver, brain, and bones (Balch et al. 2003). Several factors might be important for favoring UM liver metastasis progression, such as the invasion route used by tumoral cells. It is accepted that CM cells prefer the lymphatic system, while UM cells spread almost exclusively hematogenously. The hematogenous routes might favor dissemination of tumor cells from the eye to the liver rather than to others organs. It is also possible that the specific loose structure of the liver endothelial vasculature, presenting large fenestrae (Wisse et al. 2008), might favor liver colonization by UM cells. Another mechanism could be related to the metabolic status, which has been shown in breast cancer cells to dictate the site of metastasis (Dupuy et al. 2015).

Finally, recent data demonstrated that UM-derived exosomes expressing integrin $\alpha \mathrm{V}$ /integrin $\beta 5$ are taken up by liver-specific cells to prepare the premetastatic niches and steer the liver tropism of UM cells (Hoshino et al. 2015). In addition to favoring the nesting of UM cells, the liver might also provide a favorable environment for sustaining the growth of UM. This phenomenon could be achieved 
through liver production of HGF, which stimulates the proliferation and survival of UM cells expressing the surface receptor c-Met (Bakalian et al. 2008). A complete identification of the mechanisms mediating this tropism will undoubtedly help to improve patient surveillance and outcome.

\section{From bench to bedside: the therapeutic options}

The identification of specific biological, molecular, and genetic tumor features have led to the development of "personalized therapy"; i.e., therapies tailored to patientspecific molecular aberrations. More precisely, the discovery of the BRAF ${ }^{\mathrm{V} 600 \mathrm{E}}$ mutation led to the development of BRAF (vemurafenib and dabrafenib) and MEK (trametinib and cobimetinib) inhibitors (Sullivan and Flaherty 2015b). Bitherapy, combining both BRAF and MEK inhibitors, is the reference treatment for patients with metastatic CM harboring a mutation at codon 600 of BRAF; however, in some centers, it is superseded by immunotherapy (described below). The targeted therapies have allowed, for the first time, a $>12$-mo increase in the median overall survival of the patients (Long et al. 2014; Ugurel et al. 2016). However, despite the success of these treatments, most patients eventually develop secondary resistance and relapse.

The genetic studies suggest that conjunctival melanoma behaves more similarly to CM than UM. Although there is no standard recommendation for the treatment of patients with conjunctival melanoma, there is ample evidence to test patients for mutations at codon 600 of BRAF and assess the efficacy of the BRAF and MEK inhibitors.

Currently, there is no systemic treatment for UM once it has spread. UM metastases are remarkably refractory to conventional chemotherapy and nonsensitive to external radiotherapy. Mortality rates have not changed in the last decades. In patients with UM metastases, BRAF and/ or MEK inhibitors are generally ineffective due to the absence of the BRAF mutation (for review, see Oliva et al. 2016). However, because a phase 2 trial showed promising results with the MEK inhibitor selumetinib /Carvajal et al. 2014), there are several ongoing trials for UM patients assessing the efficacy of selumetinib in combination with chemotherapies or with PKC and AKT inhibitors (Chattopadhyay et al. 2016).

Nevertheless, the discovery of GNAQ, GNA11, CYSLTR2, and PLCB4 mutations has paved the road toward specific targeted therapies for UM. In this context, FR900359, a selective inhibitor of GNAQ/11/14, has been identified recently and shown to blunt the signaling downstream from GNAQ ${ }^{\mathrm{R} 183 \mathrm{C}}$ and $\mathrm{GNAQ}^{\mathrm{Q} 209 \mathrm{~L}}$ (Schrage et al. 2015). Moreover, compounds with anti-CYSLTR2 activity are currently being tested in phase 2 clinical trials (Wunder et al. 2010). As CYSLTR2 functions upstream of GNAQ/11, CYSLTR2 inhibitors are expected to be efficient only in UM without GNAQ/11 or PLCB4 mutations.

Inhibitors of TRIO (Blangy et al. 2006; Schmidt and Debant 2013) or ARF6 (Yoo et al. 2016) have been described and would be of wider use because they will block oncogenic signaling downstream from mutated GNAQ/ 11 and CYSLTR2, overall representing 95\% of the UM cases. These inhibitors might not be efficient in UM with PLCB4 mutations.

Finally, CM and UM might be sensitive to the same inhibitors. For example, UM with mutations in EIF1AX might benefit from inhibitors of the formation of the EIF4F complex, which is required downstream from EIF1AX for the regulation of cap-dependent translation. Such inhibitors have been described and have shown some efficacy in a preclinical model of CM (Boussemart et al. 2014). The potential targets and drugs are summarized in Table 3.

Additionally, studies have elucidated how CTLA4 (cytotoxic T-lymphocyte-associated protein 4) and PD-1 (programmed cell death 1) decrease activation of the immune system, thereby leading to the development of monoclonal antibodies against CTLA4 (ipilimumab) and PD-1 (nivolumab and pembrolizumab). These antibodies have demonstrated clear clinical benefits in patients with metastatic CM. Indeed, objective response rates are obtained at $15 \%-30 \%$ and demonstrate durable responses, reaching an 18-mo increase in median survival (Hodi et al. 2010; Topalian et al. 2014; Carlino and Long 2016). The combination of ipilimumab and nivolumab showed even greater improvements in patient overall survival compared with anti-CTLA4 or anti-PD1 monotherapy (Kaufman et al. 2013; Sullivan and Flaherty 2015a). Clinical trials investigating antibodies against PDL1 (programmed cell death ligand 1), a PD1 ligand, have demonstrated promising activity in advanced CM, albeit with generally lower response rates than PD1 antibodies (Tsai et al. 2014; Mahoney et al. 2015).

Until now, immunotherapeutic approaches targeting immune checkpoints have revealed limited efficacy in metastatic UM (Danielli et al. 2012; Algazi et al. 2016; van der Kooij et al. 2017). Ipilimumab has failed to demonstrate a clear objective clinical response (for review, see Oliva et al. 2016). Similarly, anti-PD1 (either pembrolizumab or nivolumab) or anti-PDL1 (Algazi et al. 2016) has demonstrated poor clinical activity (Algazi et al. 2016; van der Kooij et al. 2017).

The weak response of metastatic UM to immunotherapies might be ascribed to the maintenance of ocular immune privilege, which has been involved in the suppression of both adaptive and innate immune effector mechanisms (McKenna and Chen 2010). Moreover, the CM response to immunotherapies seems to be correlated to the mutational burden, which is thought to generate neoantigens (Johansson et al. 2016; Royer-Bertrand et al. 2016). The low mutational burden of UM might also explain the moderate response to immunotherapies.

Clinical trials evaluating the efficacy of pembrolizumab in monotherapy, which nevertheless has shown a more favorable response in one study (Kottschade et al. 2016), and the combination of ipilimumab and nivolumab are currently under way (Chattopadhyay et al. 2016). In the absence of rational treatment options for metastatic UM, immunotherapy should be considered, and additional clinical trials should be scheduled. In support of this 
Table 3. Clinically relevant targets in UM

\begin{tabular}{|c|c|c|c|c|}
\hline Drugs & Targets & Indication & Clinical trials in UM & Comments \\
\hline ONO-6950 & CYSLTR2 & Asthma & & Asthma: NCT01551147 \\
\hline HAMI3379 & CYSLTR2 & Asthma & & Preclinical development \\
\hline FR900359 & GNAQ/11 & Asthma & & Preclinical development \\
\hline NAV-2729 & ARF6 & $\begin{array}{l}\text { Inflammatory } \\
\text { conditions }\end{array}$ & & Preclinical development \\
\hline ITX3 & TRIO & & & Preclinical development \\
\hline TRIP & TRIO & & & Preclinical development \\
\hline FL3 & EIF1AX & & & Preclinical development \\
\hline Crizotinib & MET & Lung cancer & NCT02223819 & FDA-approved \\
\hline Cabozantinib & MET & Kidney cancer & NCT01835145 & FDA-approved \\
\hline Verteporfin & YAP & Retinopathy & & FDA-approved \\
\hline Sotrastaurin & PKC & DLBCL, UM & $\begin{array}{l}\text { NCT01801358 NCT01430416 } \\
\text { NCT02273219 }\end{array}$ & $\begin{array}{l}\text { Trials in combination with MEK of } \\
\text { PI3K inhibitors }\end{array}$ \\
\hline LXS-196 & PKC & UM & NCT02601378 & \\
\hline Trametinib & MEK & $\mathrm{CM}$ & NCT01979523 & $\begin{array}{l}\text { FDA-approved in combination with } \\
\text { BRAF inhibitor }\end{array}$ \\
\hline $\begin{array}{l}\text { Selumetinib } \\
\text { (Adjuvant) }\end{array}$ & MEK & Thyroid cancer & NCT02768766 NCT01143402 & \\
\hline
\end{tabular}

Novel potential treatment strategies (first column) against essential genetic pathway alterations (second column), clinical indications (third column), clinical trials that are under way (fourth column), and the stages of drug development (fifth column) are indicated. (DLBCL) Diffuse large B-cell lymphoma.

idea, combination therapies of checkpoint inhibitors with local, targeted, and immunotherapy for metastatic UM must be explored to determine whether they could improve patient prognosis.

Moreover, strategies using genetically modified T-cellbased adoptive immunotherapy approaches, including chimeric antigen receptor (CAR) and engineered T-cell receptor (TCR) T-cell therapies, have yielded encouraging clinical responses by overcoming immune evasion and redirecting the specificity of cytotoxic T lymphocytes to tumor cells (Sharpe and Mount 2015). Due to advances in sequencing technology, somatically mutated UM antigens (neoantigens) have been identified and have become compelling targets for immunotherapy. Adoptive immunotherapies could therefore represent therapeutic options for low mutation burden cancers such as UM.

Furthermore, PRAME is associated with class $1 \mathrm{~b}$ metastatic UM (Field et al. 2016a) and is immunogenic, increasing the attractiveness of the development of novel immune therapies for PRAME. Phase 1 clinical trials are currently evaluating the safety and immunogenicity of a PRAME vaccine (Gutzmer et al. 2016). This new strategy might soon be offered to patients with UM and improve their outcome.

\section{Conclusion}

Cutaneous and uveal melanocytes share the same embryonic origin and the same cellular function; however, they are subjected to different oncogenic transformation processes. In recent years, immense progress has been achieved in the cellular and molecular characterization of UM and skin melanoma. Large-scale genomic studies have demonstrated the direct mutagenic role of UVR in $\mathrm{CM}$ pathogenesis, whereas there is no conclusive proof linking UV exposure to UM etiology. The majority of CM $(80 \%)$ carries a mutation in BRAF, NRAS, or NF1, leading to the deregulation of the ERK pathway. In UM, activating mutations in GNAQ/11 dominate $(83 \%)$ and engage specific signaling pathways, including ARF6/ TRIO/RHO/RAC/YAP and PLC $/$ PKC/ERK cascades. Moreover, recurrent genetic alterations in BAP1, which functions in the cell cycle, cell identity, and genome integrity, are found in UM (40\%) and are associated with the development of metastasis. UM metastases display a very strong liver tropism, while CM metastases involve, almost equivalently, the lungs, liver, bones, and brain. Because of these cellular and molecular differences, the recently developed therapies (targeted and immunotherapies) that show clinical activity for metastatic CM are still ineffective in patients with metastatic UM.

Nevertheless, recent discoveries have delineated the contours of UM disease and identified targets for rational therapies. The concerted effort of talented researchers and clinicians working in the field will undoubtedly replicate in UM the extraordinary clinical advances recently achieved in CM.

\section{Acknowledgments}

We thank Dr. L. Larue (Institut Curie, Paris, France) and R. Kelsh (University of Bath, Bath, UK) for helpful discussions. This work was funded by Institut National du Cancer grant INCa_10573 to C.B. The team is "Equipe Labellisée Fondation ARC" to R.B. C.P. is a recipient from the La Ligue Nationale Contre le Cancer.

\section{References}

Aalto Y, Eriksson L, Seregard S, Larsson O, Knuutila S. 2001. Concomitant loss of chromosome 3 and whole arm losses and 
gains of chromosome 1,6 , or 8 in metastasizing primary uveal melanoma. Invest Ophthalmol Vis Sci 42: 313-317.

Ackermann J, Frutschi M, Kaloulis K, McKee T, Trumpp A, Beermann F. 2005. Metastasizing melanoma formation caused by expression of activated N-Ras ${ }^{\mathrm{Q} 61 \mathrm{~K}}$ on an INK4a-deficient background. Cancer Res 65: 4005-4011.

Adameyko I, Lallemend F, Aquino JB, Pereira JA, Topilko P, Muller T, Fritz N, Beljajeva A, Mochii M, Liste I, et al. 2009. Schwann cell precursors from nerve innervation are a cellular origin of melanocytes in skin. Cell 139: 366-379.

Algazi AP, Tsai KK, Shoushtari AN, Munhoz RR, Eroglu Z, Piulats JM, Ott PA, Johnson DB, Hwang J, Daud AI, et al. 2016. Clinical outcomes in metastatic uveal melanoma treated with PD-1 and PD-L1 antibodies. Cancer 122: 3344-3353.

Allegra M, Giacchero D, Segalen C, Dumaz N, Butori C, Hofman V, Hofman P, Lacour JP, Bertolotto C, Bahadoran P, et al. 2014. A new KIT mutation (N505I) in acral melanoma confers constitutive signaling, favors tumorigenic properties, and is sensitive to imatinib. J Invest Dermatol 134: 1473-1476.

Alsafadi S, Houy A, Battistella A, Popova T, Wassef M, Henry E, Tirode F, Constantinou A, Piperno-Neumann S, Roman-Roman S, et al. 2016. Cancer-associated SF3B1 mutations affect alternative splicing by promoting alternative branchpoint usage. Nat Commun 7: 10615.

An HK, Kim KS, Lee JW, Park MH, Moon HI, Park SJ, Baik JS, Kim $\mathrm{CH}$, Lee YC. 2014. Mimulone-induced autophagy through p53-mediated AMPK/mTOR pathway increases caspase-mediated apoptotic cell death in A549 human lung cancer cells. PLoS One 9: e114607.

Aoki H, Yamada Y, Hara A, Kunisada T. 2009. Two distinct types of mouse melanocyte: differential signaling requirement for the maintenance of non-cutaneous and dermal versus epidermal melanocytes. Development 136: 2511-2521.

Aoude LG, Wadt KA, Pritchard AL, Hayward NK. 2015. Genetics of familial melanoma: 20 years after CDKN2A. Pigment Cell Melanoma Res 28: 148-160.

Arafeh R, Qutob N, Emmanuel R, Keren-Paz A, Madore J, Elkahloun A, Wilmott JS, Gartner JJ, Di Pizio A, Winograd-Katz S, et al. 2015. Recurrent inactivating RASA2 mutations in melanoma. Nat Genet 47: 1408-1410.

Arrington JH III, Reed RJ, Ichinose H, Krementz ET. 1977. Plantar lentiginous melanoma: a distinctive variant of human cutaneous malignant melanoma. Am I Surg Pathol 1: 131-143.

Bakalian S, Marshall JC, Logan P, Faingold D, Maloney S, Di Cesare S, Martins C, Fernandes BF, Burnier MN Jr. 2008. Molecular pathways mediating liver metastasis in patients with uveal melanoma. Clin Cancer Res 14: 951-956.

Balch CM, Buzaid AC, Soong SJ, Atkins MB, Cascinelli N, Coit DG, Fleming ID, Gershenwald JE, Houghton A Jr, Kirkwood JM, et al. 2003. New TNM melanoma staging system: linking biology and natural history to clinical outcomes. Semin Surg Oncol 21: 43-52.

Barrenas ML, Lindgren F. 1990. The influence of inner ear melanin on susceptibility to TTS in humans. Scand Audiol 19: 97-102.

Bastian BC. 2014. The molecular pathology of melanoma: an integrated taxonomy of melanocytic neoplasia. Annu Rev Pathol 9: 239-271.

Bastian BC, LeBoit PE, Hamm H, Brocker EB, Pinkel D. 1998. Chromosomal gains and losses in primary cutaneous melanomas detected by comparative genomic hybridization. Cancer Res 58: 2170-2175.

Bauer J, Curtin JA, Pinkel D, Bastian BC. 2007. Congenital melanocytic nevi frequently harbor NRAS mutations but no BRAF mutations. J Invest Dermatol 127: 179-182.
Beadling C, Jacobson-Dunlop E, Hodi FS, Le C, Warrick A, Patterson J, Town A, Harlow A, Cruz F III, Azar S, et al. 2008. KIT gene mutations and copy number in melanoma subtypes. Clin Cancer Res 14: 6821-6828.

Beller TC, Maekawa A, Friend DS, Austen KF, Kanaoka Y. 2004. Targeted gene disruption reveals the role of the cysteinyl leukotriene 2 receptor in increased vascular permeability and in bleomycin-induced pulmonary fibrosis in mice. I Biol Chem 279: 46129-46134.

Bennett DC. 2008. How to make a melanoma: what do we know of the primary clonal events? Pigment Cell Melanoma Res 21: 27-38.

Berger MF, Hodis E, Heffernan TP, Deribe YL, Lawrence MS, Protopopov A, Ivanova E, Watson IR, Nickerson E, Ghosh P, et al. 2012. Melanoma genome sequencing reveals frequent PREX2 mutations. Nature 485: 502-506.

Bertolotto C. 2013. Melanoma: from melanocyte to genetic alterations and clinical options. Scientifica 2013: 635203.

Bertolotto C, Abbe P, Hemesath TJ, Bille K, Fisher DE, Ortonne JP, Ballotti R. 1998a. Microphthalmia gene product as a signal transducer in cAMP-induced differentiation of melanocytes. J Cell Biol 142: 827-835.

Bertolotto C, Busca R, Abbe P, Bille K, Aberdam E, Ortonne JP, Ballotti R. 1998b. Different cis-acting elements are involved in the regulation of TRP1 and TRP2 promoter activities by cyclic AMP: pivotal role of $M$ boxes (GTCATGTGCT) and of microphthalmia. Mol Cell Biol 18: 694-702.

Bertolotto C, Lesueur F, Giuliano S, Strub T, de Lichy M, Bille K, Dessen P, d'Hayer B, Mohamdi H, Remenieras A, et al. 2011. A SUMOylation-defective MITF germline mutation predisposes to melanoma and renal carcinoma. Nature 480: 94-98.

Besaratinia A, Pfeifer GP. 2008. Sunlight ultraviolet irradiation and BRAF V600 mutagenesis in human melanoma. Hum Mutat 29: 983-991.

Besaratinia A, Synold TW, Xi B, Pfeifer GP. 2004. G-to-T transversions and small tandem base deletions are the hallmark of mutations induced by ultraviolet a radiation in mammalian cells. Biochemistry 43: 8169-8177.

Bhat M, Robichaud N, Hulea L, Sonenberg N, Pelletier J, Topisirovic I. 2015. Targeting the translation machinery in cancer. Nat Rev Drug Discov 14: 261-278.

Blangy A, Bouquier N, Gauthier-Rouviere C, Schmidt S, Debant A, Leonetti JP, Fort P. 2006. Identification of TRIO-GEFD1 chemical inhibitors using the yeast exchange assay. Biol Cell 98: 511-522.

Bonet C, Luciani F, Ottavi JF, Leclerc J, Jouenne FM, Boncompagni M, Bille K, Hofman V, Bossis G, De Donatis GM, et al. 2017. Deciphering the role of oncogenic MITFE318K in senescence delay and melanoma progression. I Natl Cancer Inst doi: 10.1093/jnci/djw340.

Boussemart L, Malka-Mahieu H, Girault I, Allard D, Hemmingsson O, Tomasic G, Thomas M, Basmadiian C, Ribeiro N, Thuaud F, et al. 2014. eIF4F is a nexus of resistance to antiBRAF and anti-MEK cancer therapies. Nature 513: 105-109.

Brantley MA Jr, Harbour JW. 2000a. Deregulation of the Rb and p53 pathways in uveal melanoma. Am I Pathol 157: 1795-1801.

Brantley MA Jr, Harbour JW. 2000b. Inactivation of retinoblastoma protein in uveal melanoma by phosphorylation of sites in the COOH-terminal region. Cancer Res 60: 4320-4323.

Brenner M, Hearing VJ. 2008. The protective role of melanin against UV damage in human skin. Photochem Photobiol 84: 539-549. 
Bressac-de-Paillerets B, Avril MF, Chompret A, Demenais F. 2002. Genetic and environmental factors in cutaneous malignant melanoma. Biochimie 84: 67-74.

Bronner-Fraser M. 1994. Neural crest cell formation and migration in the developing embryo. FASEB I 8: 699-706.

The Cancer Genome Atlas Network. 2015. Genomic classification of cutaneous melanoma. Cell 161: 1681-1696.

Cao J, Wan L, Hacker E, Dai X, Lenna S, Jimenez-Cervantes C, Wang Y, Leslie NR, Xu GX, Widlund HR, et al. 2013. MC1R is a potent regulator of PTEN after UV exposure in melanocytes. Mol Cell 51: 409-422.

Carlino MS, Long GV. 2016. Ipilimumab combined with nivolumab: a standard of care for the treatment of advanced melanoma? Clin Cancer Res 22: 3992-3998.

Carneiro F, Kruithof BP, Balani K, Agarwal A, Gaussin V, Kos L. 2015. Relationships between melanocytes, mechanical properties and extracellular matrix composition in mouse heart valves. J Long Term Eff Med Implants 25: 17-26.

Carreira S, Goodall J, Denat L, Rodriguez M, Nuciforo P, Hoek KS, Testori A, Larue L, Goding CR. 2006. Mitf regulation of Dia1 controls melanoma proliferation and invasiveness. Genes Dev 20: 3426-3439.

Carvajal RD, Antonescu CR, Wolchok JD, Chapman PB, Roman RA, Teitcher J, Panageas KS, Busam KJ, Chmielowski B, Lutzky J, et al. 2011. KIT as a therapeutic target in metastatic melanoma. JAMA 305: 2327-2334.

Carvajal RD, Sosman JA, Quevedo JF, Milhem MM, Joshua AM, Kudchadkar RR, Linette GP, Gajewski TF, Lutzky J, Lawson $\mathrm{DH}$, et al. 2014. Effect of selumetinib vs chemotherapy on progression-free survival in uveal melanoma: a randomized clinical trial. JAMA 311: 2397-2405.

Cerami E, Gao J, Dogrusoz U, Gross BE, Sumer SO, Aksoy BA, Jacobsen A, Byrne CJ, Heuer ML, Larsson E, et al. 2012. The cBio cancer genomics portal: an open platform for exploring multidimensional cancer genomics data. Cancer Discov 2: 401-404.

Chattopadhyay C, Kim DW, Gombos DS, Oba J, Qin Y, Williams MD, Esmaeli B, Grimm EA, Wargo JA, Woodman SE, et al. 2016. Uveal melanoma: from diagnosis to treatment and the science in between. Cancer 122: 2299-2312.

Cheli Y, Ohanna M, Ballotti R, Bertolotto C. 2010. Fifteen-year quest for microphthalmia-associated transcription factor target genes. Pigment Cell Melanoma Res 23: 27-40.

Cheli Y, Giuliano S, Botton T, Rocchi S, Hofman V, Hofman P, Bahadoran P, Bertolotto C, Ballotti R. 2011. Mitf is the key molecular switch between mouse or human melanoma initiating cells and their differentiated progeny. Oncogene 30: $2307-2318$.

Cheng KC, Cahill DS, Kasai H, Nishimura S, Loeb LA. 1992. 8-hydroxyguanine, an abundant form of oxidative DNA damage, causes $\mathrm{G} \rightarrow \mathrm{T}$ and $\mathrm{A} \rightarrow \mathrm{C}$ substitutions. J Biol Chem 267: $166-172$.

Clark WH Jr, Elder DE, Van Horn M. 1986. The biologic forms of malignant melanoma. Hum Pathol 17: 443-450.

Conde-Perez A, Gros G, Longvert C, Pedersen M, Petit V, Aktary Z, Viros A, Gesbert F, Delmas V, Rambow F, et al. 2015. A caveolin-dependent and PI3K/AKT-independent role of PTEN in $\beta$-catenin transcriptional activity. Nat Commun 6: 8093.

Curtin JA, Busam K, Pinkel D, Bastian BC. 2006. Somatic activation of KIT in distinct subtypes of melanoma. J Clin Oncol 24: 4340-4346.

Damato B, Dopierala JA, Coupland SE. 2010. Genotypic profiling of 452 choroidal melanomas with multiplex ligation-dependent probe amplification. Clin Cancer Res 16: 6083-6092.
Damsky WE, Curley DP, Santhanakrishnan M, Rosenbaum LE, Platt JT, Gould Rothberg BE, Taketo MM, Dankort D, Rimm DL, McMahon M, et al. 2011. $\beta$-Catenin signaling controls metastasis in Braf-activated Pten-deficient melanomas. Cancer Cell 20: 741-754.

Danielli R, Ridolfi R, Chiarion-Sileni V, Queirolo P, Testori A, Plummer R, Boitano M, Calabro L, Rossi CD, Giacomo AM, et al. 2012. Ipilimumab in pretreated patients with metastatic uveal melanoma: safety and clinical efficacy. Cancer Immunol Immunother 61: 41-48.

Dankort D, Curley DP, Cartlidge RA, Nelson B, Karnezis AN, Damsky WE Jr, You MJ, DePinho RA, McMahon M, Bosenberg M. 2009. Braf(V600E) cooperates with Pten loss to induce metastatic melanoma. Nat Genet 41: 544-552.

Davies H, Bignell GR, Cox C, Stephens P, Edkins S, Clegg S, Teague J, Woffendin H, Garnett MJ, Bottomley W, et al. 2002. Mutations of the BRAF gene in human cancer. Nature 417: 949-954.

Davies MA, Stemke-Hale K, Tellez C, Calderone TL, Deng W, Prieto VG, Lazar AJ, Gershenwald JE, Mills GB. 2008. A novel AKT3 mutation in melanoma tumours and cell lines. $B r J$ Cancer 99: 1265-1268.

Decatur CL, Ong E, Garg N, Anbunathan H, Bowcock AM, Field MG, Harbour JW. 2016. Driver mutations in uveal melanoma: associations with gene expression profile and patient outcomes. JAMA Ophthalmol 134: 728-733.

de Lange MJ, Razzaq L, Versluis M, Verlinde S, Dogrusoz M, Bohringer S, Marinkovic M, Luyten GP, de Keizer RJ, de Gruijl FR, et al. 2015. Distribution of GNAQ and GNA11 mutation signatures in uveal melanoma points to a light dependent mutation mechanism. PLoS One 10: $\mathrm{e} 0138002$.

Delmas V, Beermann F, Martinozzi S, Carreira S, Ackermann J, Kumasaka M, Denat L, Goodall J, Luciani F, Viros A, et al. 2007. $\beta$-Catenin induces immortalization of melanocytes by suppressing p16INK4a expression and cooperates with NRas in melanoma development. Genes Dev 21: 2923-2935.

Denoyelle C, Abou-Rjaily G, Bezrookove V, Verhaegen M, Johnson TM, Fullen DR, Pointer JN, Gruber SB, Su LD, Nikiforov MA, et al. 2006. Anti-oncogenic role of the endoplasmic reticulum differentially activated by mutations in the MAPK pathway. Nat Cell Biol 8: 1053-1063.

Dhillon AS, Hagan S, Rath O, Kolch W. 2007. MAP kinase signalling pathways in cancer. Oncogene 26: 3279-3290.

Dhomen N, Reis-Filho JS, da Rocha Dias S, Hayward R, Savage K, Delmas V, Larue L, Pritchard C, Marais R. 2009. Oncogenic Braf induces melanocyte senescence and melanoma in mice. Cancer Cell 15: 294-303.

Diener-West M, Reynolds SM, Agugliaro DJ, Caldwell R, Cumming K, Earle JD, Hawkins BS, Hayman JA, Jaiyesimi I, Jampol LM, et al. 2005. Development of metastatic disease after enrollment in the COMS trials for treatment of choroidal melanoma: Collaborative Ocular Melanoma Study Group report no. 26. Arch Ophthalmol 123: 1639-1643.

Dithmar S, Diaz CE, Grossniklaus HE. 2000. Intraocular melanoma spread to regional lymph nodes: report of two cases. Retina 20: 76-79.

Dupuy F, Tabaries S, Andrzejewski S, Dong Z, Blagih J, Annis MG, Omeroglu A, Gao D, Leung S, Amir E, et al. 2015. PDK1-dependent metabolic reprogramming dictates metastatic potential in breast cancer. Cell Metab 22: 577-589.

Ehlers JP, Worley L, Onken MD, Harbour JW. 2008. Integrative genomic analysis of aneuploidy in uveal melanoma. Clin Cancer Res 14: 115-122.

Emery CM, Vijayendran KG, Zipser MC, Sawyer AM, Niu L, Kim IJ, Hatton C, Chopra R, Oberholzer PA, Karpova MB, et al. 
2009. MEK1 mutations confer resistance to MEK and B-RAF inhibition. Proc Natl Acad Sci 106: 20411-20416.

Ennen M, Keime C, Kobi D, Mengus G, Lipsker D, Thibault-Carpentier C, Davidson I. 2015. Single-cell gene expression signatures reveal melanoma cell heterogeneity. Oncogene 34: 3251-3263.

Falletta P, Sanchez-Del-Campo L, Chauhan J, Effern M, Kenyon A, Kershaw CJ, Siddaway R, Lisle R, Freter R, Daniels MJ, et al. 2017. Translation reprogramming is an evolutionarily conserved driver of phenotypic plasticity and therapeutic resistance in melanoma. Genes Dev 31: 18-33.

Feng X, Degese MS, Iglesias-Bartolome R, Vaque JP, Molinolo AA, Rodrigues M, Zaidi MR, Ksander BR, Merlino G, Sodhi A, et al. 2014. Hippo-independent activation of YAP by the GNAQ uveal melanoma oncogene through a trio-regulated rho GTPase signaling circuitry. Cancer Cell 25: 831-845.

Ferguson R, Vogelsang M, Ucisik-Akkaya E, Rai K, Pilarski R, Martinez CN, Rendleman J, Kazlow E, Nagdimov K, Osman I, et al. 2016. Genetic markers of pigmentation are novel risk loci for uveal melanoma. Sci Rep 6: 31191.

Field MG, Harbour JW. 2014. Recent developments in prognostic and predictive testing in uveal melanoma. Curr Opin Ophthalmol 25: 234-239.

Field MG, Decatur CL, Kurtenbach S, Gezgin G, van der Velden PA, Jager MJ, Kozak KN, Harbour JW. 2016a. PRAME as an independent biomarker for metastasis in uveal melanoma. Clin Cancer Res 22: 1234-1242.

Field MG, Durante MA, Decatur CL, Tarlan B, Oelschlager KM, Stone JF, Kuznetsov J, Bowcock AM, Kurtenbach S, Harbour JW. 2016b. Epigenetic reprogramming and aberrant expression of PRAME are associated with increased metastatic risk in class 1 and class 2 uveal melanomas. Oncotarget 7: 59209-59219.

Fine B, Hodakoski C, Koujak S, Su T, Saal LH, Maurer M, Hopkins B, Keniry M, Sulis ML, Mense S, et al. 2009. Activation of the PI3K pathway in cancer through inhibition of PTEN by exchange factor P-REX2a. Science 325: 1261-1265.

Fletcher O, Easton D, Anderson K, Gilham C, Jay M, Peto J. 2004. Lifetime risks of common cancers among retinoblastoma survivors. I Natl Cancer Inst 96: 357-363.

Francis JH, Wiesner T, Milman T, Won HH, Lin A, Lee V, Albert DM, Folberg R, Berger MF, Char DH, et al. 2016. Investigation of somatic GNAQ, GNA11, BAP1 and SF3B1 mutations in ophthalmic melanocytomas. Ocul Oncol Pathol 2: 171-177.

Furman C, Short SM, Subramanian RR, Zetter BR, Roberts TM. 2002. DEF-1/ASAP1 is a GTPase-activating protein (GAP) for ARF1 that enhances cell motility through a GAP-dependent mechanism. J Biol Chem 277: 7962-7969.

Furney SI, Pedersen M, Gentien D, Dumont AG, Rapinat A, Desjardins L, Turajlic S, Piperno-Neumann S, de la Grange P, Roman-Roman S, et al. 2013. SF3B1 mutations are associated with alternative splicing in uveal melanoma. Cancer Discov 3: 1122-1129.

Gao J, Aksoy BA, Dogrusoz U, Dresdner G, Gross B, Sumer SO, Sun Y, Jacobsen A, Sinha R, Larsson E, et al. 2013. Integrative analysis of complex cancer genomics and clinical profiles using the cBioPortal. Science Signal 6: pll.

Garnett MJ, Marais R. 2004. Guilty as charged: B-RAF is a human oncogene. Cancer Cell 6: 313-319.

Garraway LA, Widlund HR, Rubin MA, Getz G, Berger AJ, Ramaswamy S, Beroukhim R, Milner DA, Granter SR, Du J, et al. 2005. Integrative genomic analyses identify MITF as a lineage survival oncogene amplified in malignant melanoma. Nature 436: $117-122$.
Ghiorzo P, Pastorino L, Queirolo P, Bruno W, Tibiletti MG, Nasti S, Andreotti V, Paillerets BB, Bianchi Scarra G. 2013. Prevalence of the E318K MITF germline mutation in Italian melanoma patients: associations with histological subtypes and family cancer history. Pigment Cell Melanoma Res 26: 259-262.

Giuliano S, Cheli Y, Ohanna M, Bonet C, Beuret L, Bille K, Loubat A, Hofman V, Hofman P, Ponzio G, et al. 2010. Microphthalmia-associated transcription factor controls the DNA damage response and a lineage-specific senescence program in melanomas. Cancer Res 70: 3813-3822.

Griewank KG, Murali R. 2013. Pathology and genetics of uveal melanoma. Pathology 45: 18-27.

Griewank KG, Westekemper H, Murali R, Mach M, Schilling B, Wiesner T, Schimming T, Livingstone E, Sucker A, Grabellus F, et al. 2013. Conjunctival melanomas harbor BRAF and NRAS mutations and copy number changes similar to cutaneous and mucosal melanomas. Clin Cancer Res 19:3143-3152.

Gupta MP, Lane AM, DeAngelis MM, Mayne K, Crabtree M, Gragoudas ES, Kim IK. 2015. Clinical Characteristics of uveal melanoma in patients with germline BAP1 mutations. JAMA Ophthalmol 133: 881-887.

Gutzmer R, Rivoltini L, Levchenko E, Testori A, Utikal J, Ascierto PA, Demidov L, Grob JJ, Ridolfi R, Schadendorf D, et al. 2016. Safety and immunogenicity of the PRAME cancer immunotherapeutic in metastatic melanoma: results of a phase I dose escalation study. ESMO Open 1: e000068.

Harbour JW, Onken MD, Roberson ED, Duan S, Cao L, Worley LA, Council ML, Matatall KA, Helms C, Bowcock AM. 2010. Frequent mutation of BAP1 in metastasizing uveal melanomas. Science 330: 1410-1413.

Harbour JW, Roberson ED, Anbunathan H, Onken MD, Worley LA, Bowcock AM. 2013. Recurrent mutations at codon 625 of the splicing factor SF3B1 in uveal melanoma. Nat Genet 45: $133-135$.

Harris RS. 2013. Cancer mutation signatures, DNA damage mechanisms, and potential clinical implications. Genome Med 5: 87.

Hearle N, Damato BE, Humphreys J, Wixey J, Green H, Stone J, Easton DF, Houlston RS. 2003a. Contribution of germline mutations in BRCA2, P16(INK4A), P14(ARF) and P15 to uveal melanoma. Invest Ophthalmol Vis Sci 44: 458-462.

Hearle N, Humphreys J, Damato BE, Wort R, Talaban R, Wixey J, Green H, Easton DF, Houlston RS. 2003b. Role of MC1R variants in uveal melanoma. Br J Cancer 89: 1961-1965.

Herraiz C, Garcia-Borron JC, Jimenez-Cervantes C, Olivares C. 2017. MC1R signaling. Intracellular partners and pathophysiological implications. Biochim Biophys Acta doi: 10.1016/ j.bbadis.2017.02.027.

Hodi FS, O'Day SJ, McDermott DF, Weber RW, Sosman JA, Haanen JB, Gonzalez R, Robert C, Schadendorf D, Hassel JC, et al. 2010. Improved survival with ipilimumab in patients with metastatic melanoma. N Engl I Med 363: 711-723.

Hodis E, Watson IR, Kryukov GV, Arold ST, Imielinski M, Theurillat JP, Nickerson E, Auclair D, Li L, Place C, et al. 2012. A landscape of driver mutations in melanoma. Cell 150: 251-263.

Hoek KS, Goding CR. 2010. Cancer stem cells versus phenotypeswitching in melanoma. Pigment Cell Melanoma Res 23: 746-759.

Hoek KS, Eichhoff OM, Schlegel NC, Dobbeling U, Kobert N, Schaerer L, Hemmi S, Dummer R. 2008. In vivo switching of human melanoma cells between proliferative and invasive states. Cancer Res 68: 650-656. 
Horn S, Figl A, Rachakonda PS, Fischer C, Sucker A, Gast A, Kadel S, Moll I, Nagore E, Hemminki K, et al. 2013. TERT promoter mutations in familial and sporadic melanoma. Science 339: 959-961.

Horrigan SK, Courville P, Sampey D, Zhou F, Cai S, Reproducibility Project: Cancer B. 2017. Replication study: melanoma genome sequencing reveals frequent PREX2 mutations. Elife 6: e21634.

Hoshino A, Costa-Silva B, Shen TL, Rodrigues G, Hashimoto A, Tesic Mark M, Molina H, Kohsaka S, Di Giannatale A, Ceder $\mathrm{S}$, et al. 2015. Tumour exosome integrins determine organotropic metastasis. Nature 527: 329-335.

Hussussian CI, Struewing JP, Goldstein AM, Higgins PA, Ally DS, Sheahan MD, Clark WH Jr, Tucker MA, Dracopoli NC. 1994. Germline p16 mutations in familial melanoma. Nat Genet 8: $15-21$.

Ismail IH, Davidson R, Gagne JP, Xu ZZ, Poirier GG, Hendzel MJ. 2014. Germline mutations in BAP1 impair its function in DNA double-strand break repair. Cancer Res 74: 4282-4294.

Janku F, Lee JJ, Tsimberidou AM, Hong DS, Naing A, Falchook GS, Fu S, Luthra R, Garrido-Laguna I, Kurzrock R. 2011. PIK3CA mutations frequently coexist with RAS and BRAF mutations in patients with advanced cancers. PLoS One 6: e22769.

Johannessen CM, Johnson LA, Piccioni F, Townes A, Frederick DT, Donahue MK, Narayan R, Flaherty KT, Wargo JA, Root $\mathrm{DE}$, et al. 2013. A melanocyte lineage program confers resistance to MAP kinase pathway inhibition. Nature 504: 138-142.

Johansson P, Aoude LG, Wadt K, Glasson WJ, Warrier SK, Hewitt AW, Kiilgaard JF, Heegaard S, Isaacs T, Franchina M, et al. 2016. Deep sequencing of uveal melanoma identifies a recurrent mutation in PLCB4. Oncotarget 7: 4624-4631.

Jovanovic P, Mihajlovic M, Djordjevic-Jocic J, Vlajkovic S, Cekic S, Stefanovic V. 2013. Ocular melanoma: an overview of the current status. Int J Clin Exp Pathol 6: 1230-1244.

Kaufman HL, Kirkwood JM, Hodi FS, Agarwala S, Amatruda T, Bines SD, Clark JI, Curti B, Ernstoff MS, Gajewski T, et al. 2013. The Society for Immunotherapy of Cancer consensus statement on tumour immunotherapy for the treatment of cutaneous melanoma. Nat Rev Clin Oncol 10: 588-598.

Kemper K, Krijgsman O, Cornelissen-Steijger P, Shahrabi A, Weeber F, Song JY, Kuilman T, Vis DI, Wessels LF, Voest EE, et al. 2015. Intra- and inter-tumor heterogeneity in a vemurafenib-resistant melanoma patient and derived xenografts. EMBO Mol Med 7: 1104-1118.

Kenawy N, Lake SL, Coupland SE, Damato BE. 2013. Conjunctival melanoma and melanocytic intra-epithelial neoplasia. Eye (Lond) 27: 142-152.

Konieczkowski DJ, Johannessen CM, Abudayyeh O, Kim JW, Cooper ZA, Piris A, Frederick DT, Barzily-Rokni M, Straussman R, Haq R, et al. 2014. A melanoma cell state distinction influences sensitivity to MAPK pathway inhibitors. Cancer Discov 4: 816-827.

Kottschade LA, McWilliams RR, Markovic SN, Block MS, Villasboas Bisneto J, Pham AQ, Esplin BL, Dronca RS. 2016. The use of pembrolizumab for the treatment of metastatic uveal melanoma. Melanoma Res 26: 300-303.

Krauthammer M, Kong Y, Ha BH, Evans P, Bacchiocchi A, McCusker JP, Cheng E, Davis MJ, Goh G, Choi M, et al. 2012. Exome sequencing identifies recurrent somatic RAC1 mutations in melanoma. Nat Genet 44: 1006-1014.

Krauthammer M, Kong Y, Bacchiocchi A, Evans P, Pornputtapong N, Wu C, McCusker JP, Ma S, Cheng E, Straub R, et al. 2015. Exome sequencing identifies recurrent mutations in
NF1 and RASopathy genes in sun-exposed melanomas. Nat Genet 47: 996-1002.

Krygier G, Lombardo K, Vargas C, Alvez I, Costa R, Ros M, Echenique M, Navarro V, Delgado L, Viola A, et al. 2001. Familial uveal melanoma: report on three sibling cases. Br J Ophthalmol 85: 1007-1008.

Kujala E, Kivela T. 2005. Tumor, node, metastasis classification of malignant ciliary body and choroidal melanoma evaluation of the 6th edition and future directions. Ophthalmology 112: $1135-1144$.

Landreville S, Agapova OA, Matatall KA, Kneass ZT, Onken MD, Lee RS, Bowcock AM, Harbour JW. 2012. Histone deacetylase inhibitors induce growth arrest and differentiation in uveal melanoma. Clin Cancer Res 18: 408-416.

Landsberg J, Kohlmeyer J, Renn M, Bald T, Rogava M, Cron M, Fatho M, Lennerz V, Wolfel T, Holzel M, et al. 2012. Melanomas resist $\mathrm{T}$-cell therapy through inflammation-induced reversible dedifferentiation. Nature 490: 412-416.

Larue L, Delmas V. 2006. The WNT/ $\beta$-catenin pathway in melanoma. Front Biosci 11: 733-742.

Lawrence MS, Stojanov P, Polak P, Kryukov GV, Cibulskis K, Sivachenko A, Carter SL, Stewart C, Mermel CH, Roberts SA, et al. 2013. Mutational heterogeneity in cancer and the search for new cancer-associated genes. Nature 499: 214-218.

Levin MD, Lu MM, Petrenko NB, Hawkins BJ, Gupta TH, Lang D, Buckley PT, Jochems J, Liu F, Spurney CF, et al. 2009. Melanocyte-like cells in the heart and pulmonary veins contribute to atrial arrhythmia triggers. J Clin Invest 119: 3420-3436.

Long GV, Stroyakovskiy D, Gogas H, Levchenko E, de Braud F, Larkin J, Garbe C, Jouary T, Hauschild A, Grob JJ, et al. 2014. Combined BRAF and MEK inhibition versus BRAF inhibition alone in melanoma. N Engl J Med 371: 1877-1888.

Lyon AM, Tesmer JJ. 2013. Structural insights into phospholipase C- $\beta$ function. Mol Pharmacol 84: 488-500.

Mahoney KM, Freeman GJ, McDermott DF. 2015. The next immune-checkpoint inhibitors: PD-1/PD-L1 blockade in melanoma. Clin Ther 37: 764-782.

Martin M, Masshofer L, Temming P, Rahmann S, Metz C, Bornfeld N, van de Nes J, Klein-Hitpass L, Hinnebusch AG, Horsthemke B, et al. 2013. Exome sequencing identifies recurrent somatic mutations in EIF1AX and SF3B1 in uveal melanoma with disomy 3. Nat Genet 45: 933-936.

Massoumi R, Nielsen CK, Azemovic D, Sjolander A. 2003. Leukotriene D4-induced adhesion of Caco- 2 cells is mediated by prostaglandin E2 and upregulation of $\alpha 2 \beta 1$-integrin. Exp Cell Res 289: 342-351.

Matatall KA, Agapova OA, Onken MD, Worley LA, Bowcock AM, Harbour JW. 2013. BAP1 deficiency causes loss of melanocytic cell identity in uveal melanoma. BMC Cancer 13: 371 .

Mayor R, Theveneau E. 2013. The neural crest. Development 140: 2247-2251.

McKenna KC, Chen PW. 2010. Influence of immune privilege on ocular tumor development. Ocul Immunol Inflamm 18: 80-90.

McLaughlin CC, Wu XC, Jemal A, Martin HJ, Roche LM, Chen VW. 2005. Incidence of noncutaneous melanomas in the U. S. Cancer 103: 1000-1007.

Metzelaar-Blok JA, ter Huurne JA, Hurks HM, Keunen JE, Jager MJ, Gruis NA. 2001. Characterization of melanocortin-1 receptor gene variants in uveal melanoma patients. Invest Ophthalmol Vis Sci 42: 1951-1954.

Meyer N, Penn LZ. 2008. Reflecting on 25 years with MYC. Nat Rev Cancer 8: 976-990.

Mezhybovska M, Wikstrom K, Ohd JF, Sjolander A. 2005. Pro-inflammatory mediator leukotriene D4 induces transcriptional 
activity of potentially oncogenic genes. Biochem Soc Transac 33: 698-700.

Michaloglou C, Vredeveld LC, Soengas MS, Denoyelle C, Kuilman T, van der Horst CM, Majoor DM, Shay JW, Mooi WJ, Peeper DS. 2005. BRAFE600-associated senescence-like cell cycle arrest of human naevi. Nature 436: 720-724.

Mirmohammadsadegh A, Marini A, Nambiar S, Hassan M, Tannapfel A, Ruzicka T, Hengge UR. 2006. Epigenetic silencing of the PTEN gene in melanoma. Cancer Res 66: 6546-6552.

Missotten GS, Keijser S, De Keizer RJ, De Wolff-Rouendaal D. 2005. Conjunctival melanoma in the Netherlands: a nationwide study. Invest Ophthalmol Vis Sci 46: 75-82.

Mitra D, Luo X, Morgan A, Wang J, Hoang MP, Lo J, Guerrero CR, Lennerz JK, Mihm MC, Wargo JA, et al. 2012. An ultravioletradiation-independent pathway to melanoma carcinogenesis in the red hair/fair skin background. Nature 491: 449-453.

Mong S, Miller J, Wu HL, Crooke ST. 1988. Leukotriene D4 receptor-mediated hydrolysis of phosphoinositide and mobilization of calcium in sheep tracheal smooth muscle cells. J Pharmacol Exp Ther 244: 508-515.

Moore AR, Ceraudo E, Sher JJ, Guan Y, Shoushtari AN, Chang MT, Zhang JQ, Walczak EG, Kazmi MA, Taylor BS, et al. 2016. Recurrent activating mutations of G-protein-coupled receptor CYSLTR2 in uveal melanoma. Nat Genet 48: 675-680.

Morelli JG, Yohn JJ, Lyons MB, Murphy RC, Norris DA. 1989. Leukotrienes C4 and D4 as potent mitogens for cultured human neonatal melanocytes. J Invest Dermatol 93: 719-722.

Muller T, Stein U, Poletti A, Garzia L, Rothley M, Plaumann D, Thiele W, Bauer M, Galasso A, Schlag P, et al. 2010. ASAP1 promotes tumor cell motility and invasiveness, stimulates metastasis formation in vivo, and correlates with poor survival in colorectal cancer patients. Oncogene 29: 2393-2403.

Muller J, Krijgsman O, Tsoi J, Robert L, Hugo W, Song C, Kong X, Possik PA, Cornelissen-Steijger PD, Foppen MH, et al. 2014. Low MITF/AXL ratio predicts early resistance to multiple targeted drugs in melanoma. Nat Commun 5: 5712.

Murali R, Wiesner T, Rosenblum MK, Bastian BC. 2012. GNAQ and GNA11 mutations in melanocytomas of the central nervous system. Acta Neuropathol 123: 457-459.

Nallet-Staub F, Marsaud V, Li L, Gilbert C, Dodier S, Bataille V, Sudol M, Herlyn M, Mauviel A. 2014. Pro-invasive activity of the Hippo pathway effectors YAP and TAZ in cutaneous melanoma. J Invest Dermatol 134: 123-132.

Network TCGA. 2015. Genomic classification of cutaneous melanoma. Cell 161: 1681-1696.

Nikolaev SI, Rimoldi D, Iseli C, Valsesia A, Robyr D, Gehrig C, Harshman K, Guipponi M, Bukach O, Zoete V, et al. 2011. Exome sequencing identifies recurrent somatic MAP2K1 and MAP2K2 mutations in melanoma. Nat Genet 44: 133-139.

Ohanna M, Giuliano S, Bonet C, Imbert V, Hofman V, Zangari I, Bille K, Robert C, Bressac-de Paillerets B, Hofman P, et al. 2011. Senescent cells develop a PARP-1 and nuclear factorкB-associated secretome (PNAS). Genes Dev 25: 1245-1261.

Oliva M, Rullan AJ, Piulats JM. 2016. Uveal melanoma as a target for immune-therapy. Ann Transl Med 4: 172.

Onken MD, Worley LA, Ehlers JP, Harbour JW. 2004. Gene expression profiling in uveal melanoma reveals two molecular classes and predicts metastatic death. Cancer Res 64: 7205-7209.

Onken MD, Ehlers JP, Worley LA, Makita J, Yokota Y, Harbour JW. 2006. Functional gene expression analysis uncovers phenotypic switch in aggressive uveal melanomas. Cancer Res 66: 4602-4609.
Onken MD, Worley LA, Long MD, Duan S, Council ML, Bowcock AM, Harbour JW. 2008. Oncogenic mutations in GNAQ occur early in uveal melanoma. Invest Ophthalmol Vis Sci 49: 5230-5234.

Onken MD, Worley LA, Harbour JW. 2010a. Association between gene expression profile, proliferation and metastasis in uveal melanoma. Curr Eye Res 35: 857-863.

Onken MD, Worley LA, Tuscan MD, Harbour JW. 2010b. An accurate, clinically feasible multi-gene expression assay for predicting metastasis in uveal melanoma. I Mol Diagnos 12: 461-468.

Patel PL, Suram A, Mirani N, Bischof O, Herbig U. 2016. Derepression of hTERT gene expression promotes escape from oncogene-induced cellular senescence. Proc Natl Acad Sci 113: E5024-E5033.

Pirker C, Holzmann K, Spiegl-Kreinecker S, Elbling L, Thallinger C, Pehamberger H, Micksche M, Berger W. 2003. Chromosomal imbalances in primary and metastatic melanomas: over-representation of essential telomerase genes. Melanoma Res 13: 483-492.

Platz A, Egyhazi S, Ringborg U, Hansson J. 2008. Human cutaneous melanoma: a review of NRAS and BRAF mutation frequencies in relation to histogenetic subclass and body site. Mol Oncol 1: 395-405.

Pollock PM, Harper UL, Hansen KS, Yudt LM, Stark M, Robbins CM, Moses TY, Hostetter G, Wagner U, Kakareka J, et al. 2003. High frequency of BRAF mutations in nevi. Nat Genet 33: $19-20$.

Rees JL. 2004. The genetics of sun sensitivity in humans. Am J Hum Genet 75: 739-751.

Riesenberg S, Groetchen A, Siddaway R, Bald T, Reinhardt J, Smorra D, Kohlmeyer J, Renn M, Phung B, Aymans P, et al. 2015. MITF and c-Jun antagonism interconnects melanoma dedifferentiation with pro-inflammatory cytokine responsiveness and myeloid cell recruitment. Nat Commun 6: 8755 .

Rietschel P, Panageas KS, Hanlon C, Patel A, Abramson DH, Chapman PB. 2005. Variates of survival in metastatic uveal melanoma. J Clin Oncol 23: 8076-8080.

Royer-Bertrand B, Torsello M, Rimoldi D, El Zaoui I, Cisarova K, Pescini-Gobert R, Raynaud F, Zografos L, Schalenbourg A, Speiser D, et al. 2016. Comprehensive genetic landscape of uveal melanoma by whole-genome sequencing. Am I Hum Genet 99: 1190-1198.

Sarna T. 1992. Properties and function of the ocular melanin-a photobiophysical view. I Photochem Photobiol B Biol 12: 215-258.

Scelo G, Constantinescu V, Csiki I, Zaridze D, Szeszenia-Dabrowska N, Rudnai P, Lissowska J, Fabianova E, Cassidy A, Slamova A, et al. 2004. Occupational exposure to vinyl chloride, acrylonitrile and styrene and lung cancer risk (europe). Cancer Causes Control 15: 445-452.

Schioth HB, Phillips SR, Rudzish R, Birch-Machin MA, Wikberg JE, Rees JL. 1999. Loss of function mutations of the human melanocortin 1 receptor are common and are associated with red hair. Biochem Biophys Res Commun 260: 488-491.

Schmidt S, Debant A. 2013. Aptamer-derived peptide inhibitors of Rho guanine nucleotide exchange factors. Enzymes 33: 147-168.

Schrage R, Schmitz AL, Gaffal E, Annala S, Kehraus S, Wenzel D, Bullesbach KM, Bald T, Inoue A, Shinjo Y, et al. 2015. The experimental power of FR900359 to study Gq-regulated biological processes. Nat Commun 6: 10156.

Seddon JM, Gragoudas ES, Glynn RJ, Egan KM, Albert DM, Blitzer PH. 1990. Host factors, UV radiation, and risk of uveal 
melanoma. A case-control study. Arch Ophthalmol 108: 1274-1280.

Sharpe M, Mount N. 2015. Genetically modified T cells in cancer therapy: opportunities and challenges. Dis Model Mech 8: 337-350.

Sherr CJ, McCormick F. 2002. The RB and p53 pathways in cancer. Cancer Cell 2: 103-112.

Shields CL, Ganguly A, Bianciotto CG, Turaka K, Tavallali A, Shields JA. 2011a. Prognosis of uveal melanoma in 500 cases using genetic testing of fine-needle aspiration biopsy specimens. Ophthalmology 118: 396-401.

Shields CL, Markowitz JS, Belinsky I, Schwartzstein H, George NS, Lally SE, Mashayekhi A, Shields JA. 2011b. Conjunctival melanoma: outcomes based on tumor origin in 382 consecutive cases. Ophthalmology 118: 389-395.e1-2.

Shtivelman E, Davies MQ, Hwu P, Yang J, Lotem M, Oren M, Flaherty KT, Fisher DE. 2014. Pathways and therapeutic targets in melanoma. Oncotarget 5: 1701-1752.

Shull AY, Latham-Schwark A, Ramasamy P, Leskoske K, Oroian D, Birtwistle MR, Buckhaults PJ. 2012. Novel somatic mutations to PI3K pathway genes in metastatic melanoma. PLoS One 7: e43369.

Singh AD, Bergman L, Seregard S. 2005. Uveal melanoma: epidemiologic aspects. Ophthalmol Clin North Am 18: 75-84.

Singh AD, Topham A. 2003. Incidence of uveal melanoma in the United States: 1973-1997. Ophthalmology 110: 956-961.

Steingrimsson E, Copeland NG, Jenkins NA. 2004. Melanocytes and the microphthalmia transcription factor network. Annu Rev Genet 38: 365-411.

Strub T, Giuliano S, Ye T, Bonet C, Keime C, Kobi D, Le Gras S, Cormont M, Ballotti R, Bertolotto C, et al. 2011. Essential role of microphthalmia transcription factor for DNA replication, mitosis and genomic stability in melanoma. Oncogene 30: 2319-2332.

Sturm RA, Larsson M. 2009. Genetics of human iris colour and patterns. Pigment Cell Melanoma Res 22: 544-562.

Sullivan RJ, Flaherty KT. 2015a. Immunotherapy: anti-PD-1 therapies-a new first-line option in advanced melanoma. Nat Rev Clin Oncol 12: 625-626.

Sullivan RJ, Flaherty KT. 2015b. New strategies in melanoma: entering the era of combinatorial therapy. Clin Cancer Res 21: 2424-2435.

Sveen A, Kilpinen S, Ruusulehto A, Lothe RA, Skotheim RI. 2016. Aberrant RNA splicing in cancer; expression changes and driver mutations of splicing factor genes. Oncogene 35: 2413-2427.

Tachibana M. 1999. Sound needs sound melanocytes to be heard. Pigment Cell Res 12: 344-354.

Takeda K, Takahashi NH, Shibahara S. 2007. Neuroendocrine functions of melanocytes: beyond the skin-deep melanin maker. Tohoku J Exp Med 211: 201-221.

Tas F. 2012. Metastatic behavior in melanoma: timing, pattern, survival, and influencing factors. J Oncol 2012: 647684.

Tatsi C, Bacopoulou F, Lyssikatos C, Belyavskaya E, Faucz FR, Stratakis CA. 2016. Sporadic melanotic schwannoma with overlapping features of melanocytoma bearing a GNA11 mutation in an adolescent girl. Pediatr Blood Cancer.

Thomas NE. 2006. BRAF somatic mutations in malignant melanoma and melanocytic naevi. Melanoma Res 16: 97-103.

Tirosh I, Izar B, Prakadan SM, Wadsworth MH II, Treacy D, Trombetta JJ, Rotem A, Rodman C, Lian C, Murphy G, et al. 2016. Dissecting the multicellular ecosystem of metastatic melanoma by single-cell RNA-seq. Science 352: 189-196.

Topalian SL, Sznol M, McDermott DF, Kluger HM, Carvajal RD, Sharfman WH, Brahmer JR, Lawrence DP, Atkins MB, Powd- erly JD, et al. 2014. Survival, durable tumor remission, and long-term safety in patients with advanced melanoma receiving nivolumab. J Clin Oncol 32: 1020-1030.

Triay E, Bergman L, Nilsson B, All-Ericsson C, Seregard S. 2009. Time trends in the incidence of conjunctival melanoma in Sweden. Br J Ophthalmol 93: 1524-1528.

Trolet I, Hupe P, Huon I, Lebigot I, Decraene C, Delattre O, Sastre-Garau X, Saule S, Thiery JP, Plancher C, et al. 2009. Genomic profiling and identification of high-risk uveal melanoma by array $\mathrm{CGH}$ analysis of primary tumors and liver metastases. Invest Ophthalmol Vis Sci 50: 2572-2580.

Tsai KK, Zarzoso I, Daud AI. 2014. PD-1 and PD-L1 antibodies for melanoma. Hum Vaccin Immunother 10: 3111-3116.

Tsai T, Vu C, Henson DE. 2005. Cutaneous, ocular and visceral melanoma in African Americans and Caucasians. Melanoma Res 15: 213-217.

Tsao H, Bevona C, Goggins W, Quinn T. 2003. The transformation rate of moles (melanocytic nevi) into cutaneous melanoma: a population-based estimate. Arch Dermatol 139: 282-288.

Tsao H, Goel V, Wu H, Yang G, Haluska FG. 2004. Genetic interaction between NRAS and BRAF mutations and PTEN/ MMAC1 inactivation in melanoma. I Invest Dermatol 122: 337-341.

Ugurel S, Rohmel J, Ascierto PA, Flaherty KT, Grob JJ, Hauschild A, Larkin J, Long GV, Lorigan P, McArthur GA, et al. 2016. Survival of patients with advanced metastatic melanoma: the impact of novel therapies. Eur J Cancer 53: 125-134.

Vajdic CM, Kricker A, Giblin M, McKenzie J, Aitken J, Giles GG, Armstrong BK. 2002. Sun exposure predicts risk of ocular melanoma in Australia. Int J Cancer 101: 175-182.

Vajdic C, Kricker A, Duffy DL, Aitken JF, Stark M, ter Huurne JA, Martin NG, Armstrong BK, Hayward NK. 2003. Ocular melanoma is not associated with CDKN2A or MC1R variants-a population-based study. Melanoma Res 13: 409-413.

Van Allen EM, Wagle N, Sucker A, Treacy DJ, Johannessen CM, Goetz EM, Place CS, Taylor-Weiner A, Whittaker S, Kryukov $\mathrm{GV}$, et al. 2014. The genetic landscape of clinical resistance to RAF inhibition in metastatic melanoma. Cancer Discov 4: 94-109.

van den Bosch T, Kilic E, Paridaens D, de Klein A. 2010. Genetics of uveal melanoma and cutaneous melanoma: two of a kind? Dermatol Res Pract 2010: 360136.

van den Bosch T, van Beek JG, Vaarwater J, Verdijk RM, Naus NC, Paridaens D, de Klein A, Kilic E. 2012. Higher percentage of FISH-determined monosomy 3 and $8 \mathrm{q}$ amplification in uveal melanoma cells relate to poor patient prognosis. Invest Ophthalmol Vis Sci 53: 2668-2674.

van der Kooij MK, Joosse A, Speetjens FM, Hospers GA, Bisschop C, de Groot JW, Koornstra R, Blank CU, Kapiteijn E. 2017. Anti-PD1 treatment in metastatic uveal melanoma in the Netherlands. Acta Oncol 56: 101-103.

van der Velden PA, Metzelaar-Blok JA, Bergman W, Monique H, Hurks H, Frants RR, Gruis NA, Jager MJ. 2001. Promoter hypermethylation: a common cause of reduced p16(INK4a) expression in uveal melanoma. Cancer Res 61: 5303-5306.

Van Raamsdonk CD, Bezrookove V, Green G, Bauer J, Gaugler L, O'Brien JM, Simpson EM, Barsh GS, Bastian BC. 2009. Frequent somatic mutations of GNAQ in uveal melanoma and blue naevi. Nature 457: 599-602.

Van Raamsdonk CD, Griewank KG, Crosby MB, Garrido MC, Vemula S, Wiesner T, Obenauf AC, Wackernagel W, Green G, Bouvier N, et al. 2010. Mutations in GNA11 in uveal melanoma. N Engl I Med 363: 2191-2199. 
Verfaillie A, Imrichova H, Atak ZK, Dewaele M, Rambow F, Hulselmans G, Christiaens V, Svetlichnyy D, Luciani F, Van den Mooter L, et al. 2015. Decoding the regulatory landscape of melanoma reveals TEADS as regulators of the invasive cell state. Nat Commun 6: 6683.

Versluis M, de Lange MJ, van Pelt SI, Ruivenkamp CA, Kroes WG, Cao J, Jager MJ, Luyten GP, van der Velden PA. 2015. Digital PCR validates $8 \mathrm{q}$ dosage as prognostic tool in uveal melanoma. PLoS One 10: e0116371.

Villanueva J, Infante JR, Krepler C, Reyes-Uribe P, Samanta M, Chen HY, Li B, Swoboda RK, Wilson M, Vultur A, et al. 2013. Concurrent MEK2 mutation and BRAF amplification confer resistance to BRAF and MEK inhibitors in melanoma. Cell Rep 4: 1090-1099.

Vogelstein B, Papadopoulos N, Velculescu VE, Zhou S, Diaz LA Jr, Kinzler KW. 2013. Cancer genome landscapes. Science 339: 1546-1558.

Vredeveld LC, Possik PA, Smit MA, Meissl K, Michaloglou C, Horlings HM, Ajouaou A, Kortman PC, Dankort D, McMahon $\mathrm{M}$, et al. 2012. Abrogation of $\mathrm{BRAF}^{\mathrm{V} 600 \mathrm{E}}$-induced senescence by PI3K pathway activation contributes to melanomagenesis. Genes Dev 26: 1055-1069.

Wakamatsu K, Hu DN, McCormick SA, Ito S. 2008. Characterization of melanin in human iridal and choroidal melanocytes from eyes with various colored irides. Pigment Cell Melanoma Res 21: 97-105.

Wei X, Walia V, Lin JC, Teer JK, Prickett TD, Gartner J, Davis S, Program NCS, Stemke-Hale K, Davies MA, et al. 2011. Exome sequencing identifies GRIN2A as frequently mutated in melanoma. Nat Genet 43: 442-446.

Weyden LV, Arends MJ, Campbell AD, Bald T, Wardle-Jones $\mathrm{H}$, Griggs N, Velasco-Herrera MD, Tuting T, Sansom OJ, Karp NA, et al. 2017. Genome-wide in vivo screen identifies novel host regulators of metastatic colonization. Nature 541: 233-236.

Wiesner T, Obenauf AC, Murali R, Fried I, Griewank KG, Ulz P, Windpassinger C, Wackernagel W, Loy S, Wolf I, et al. 2011. Germline mutations in BAP1 predispose to melanocytic tumors. Nat Genet 43: 1018-1021.

Wikstrom K, Juhas M, Sjolander A. 2003a. The anti-apoptotic effect of leukotriene D4 involves the prevention of caspase 8 activation and Bid cleavage. Biochem J 371: 115-124.

Wikstrom K, Ohd JF, Sjolander A. 2003b. Regulation of leukotriene-dependent induction of cyclooxygenase-2 and Bcl-2. Biochem Biophys Res Commun 302: 330-335.

Wilson YM, Richards KL, Ford-Perriss ML, Panthier JJ, Murphy M. 2004. Neural crest cell lineage segregation in the mouse neural tube. Development 131: 6153-6162.

Wisse E, Jacobs F, Topal B, Frederik P, De Geest B. 2008. The size of endothelial fenestrae in human liver sinusoids: implications for hepatocyte-directed gene transfer. Gene Ther 15: 1193-1199.
Wong JR, Nanji AA, Galor A, Karp CL. 2014. Management of conjunctival malignant melanoma: a review and update. Expert Rev Ophthalmol 9: 185-204.

Wu H, Goel V, Haluska FG. 2003. PTEN signaling pathways in melanoma. Oncogene 22: 3113-3122.

Wunder F, Tinel H, Kast R, Geerts A, Becker EM, Kolkhof P, Hutter J, Erguden J, Harter M. 2010. Pharmacological characterization of the first potent and selective antagonist at the cysteinyl leukotriene $2\left(\mathrm{CysLT}_{2}\right)$ receptor. $\mathrm{Br}$ I Pharmacol 160: 399-409.

Yavuzyigitoglu S, Koopmans AE, Verdijk RM, Vaarwater J, Eussen B, van Bodegom A, Paridaens D, Kilic E, de Klein A. 2016. Uveal melanomas with SF3B1 mutations: a distinct subclass associated with late-onset metastases. Ophthalmology 123: $1118-1128$.

Yokoyama S, Woods SL, Boyle GM, Aoude LG, MacGregor S, Zismann V, Gartside M, Cust AE, Haq R, Harland M, et al. 2011. A novel recurrent mutation in MITF predisposes to familial and sporadic melanoma. Nature 480: 99-103.

Yoo JH, Shi DS, Grossmann AH, Sorensen LK, Tong Z, Mleynek TM, Rogers A, Zhu W, Richards JR, Winter JM, et al. 2016. ARF6 is an actionable node that orchestrates oncogenic GNAQ signaling in uveal melanoma. Cancer Cell 29: 889-904.

Yu FX, Luo J, Mo JS, Liu G, Kim YC, Meng Z, Zhao L, Peyman G, Ouyang $\mathrm{H}$, Jiang $\mathrm{W}$, et al. 2014. Mutant $\mathrm{Gq} / 11$ promote uveal melanoma tumorigenesis by activating YAP. Cancer Cell 25: 822-830.

Zbytek B, Carlson JA, Granese J, Ross J, Mihm MC Jr, Slominski A. 2008. Current concepts of metastasis in melanoma. Expert Rev Dermatol 3: 569-585.

Zecca L, Casella L, Albertini A, Bellei C, Zucca FA, Engelen M, Zadlo A, Szewczyk G, Zareba M, Sarna T. 2008. Neuromelanin can protect against iron-mediated oxidative damage in system modeling iron overload of brain aging and Parkinson's disease. J Neurochem 106: 1866-1875.

Zhang J, Manley JL. 2013. Misregulation of pre-mRNA alternative splicing in cancer. Cancer Discov 3: 1228-1237.

Zhang T, Dutton-Regester K, Brown KM, Hayward NK. 2016. The genomic landscape of cutaneous melanoma. Pigment Cell Melanoma Res 29: 266-283.

Zhuang D, Mannava S, Grachtchouk V, Tang WH, Patil S, Wawrzyniak JA, Berman AE, Giordano TJ, Prochownik EV, Soengas MS, et al. 2008. C-MYC overexpression is required for continuous suppression of oncogene-induced senescence in melanoma cells. Oncogene 27: 6623-6634.

Zuo L, Weger I, Yang Q, Goldstein AM, Tucker MA, Walker GJ, Hayward N, Dracopoli NC. 1996. Germline mutations in the p16INK4a binding domain of CDK4 in familial melanoma. Nat Genet 12: 97-99. 


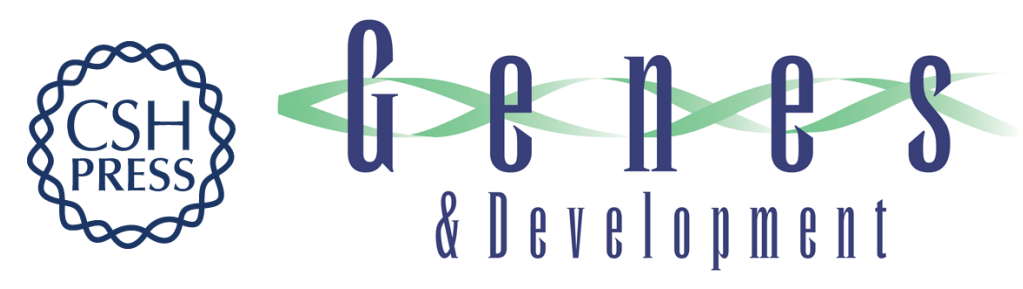

\section{Focus on cutaneous and uveal melanoma specificities}

Charlotte Pandiani, Guillaume E. Béranger, Justine Leclerc, et al.

Genes Dev. 2017, 31:

Access the most recent version at doi:10.1101/gad.296962.117

References This article cites 230 articles, 63 of which can be accessed free at: http://genesdev.cshlp.org/content/31/8/724.full.html\#ref-list-1

Creative This article is distributed exclusively by Cold Spring Harbor Laboratory Press for the first Commons six months after the full-issue publication date (see License http://genesdev.cshlp.org/site/misc/terms.xhtml). After six months, it is available under a Creative Commons License (Attribution-NonCommercial 4.0 International), as described at http://creativecommons.org/licenses/by-nc/4.0/.

Email Alerting Receive free email alerts when new articles cite this article - sign up in the box at the top Service right corner of the article or click here.

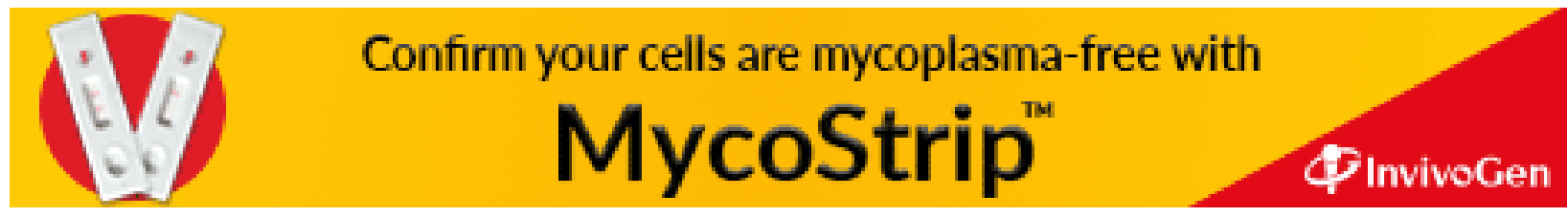

